\title{
FLOW BOILING IN MICRO-PASSAGES: DEVELOPMENTS IN FUNDAMENTAL ASPECTS AND APPLICATIONS
}

\author{
Tassos G. Karayiannis ${ }^{1}$ and Mohamed M. Mahmoud ${ }^{2}$ \\ ${ }^{1}$ Department of Mechanical and Aerospace Engineering \\ Brunel University London, Uxbridge, UP8 3PH, UK \\ ${ }^{2}$ Faculty of Engineering, Zagazig University, Zagazig, 44519, Egypt
}

Flow boiling in mini to micro passages located at the heat source, and as part of a thermal management system, has been identified as a possible way to remove the increasing high heat fluxes generated by high power electronic devices due to their capability of high heat transfer rates with small surface temperature variations. However, some still unresolved fundamental issues hinder the possible full adoption of this technology. These relate to the prevailing flow patterns, heat transfer rates and pressure drop in such geometries, and their dependence on key parameters. The possible major applications of flow boiling in microchannels are first mentioned in this paper, highlighting the requirements and the challenges of the thermal management of each application. The paper then presents new experimental research by the present authors as well as research reported in the literature on flow boiling in single tubes and rectangular multi microchannels to help elucidate the following fundamental issues: the definition of a microchannel, prevailing flow patterns, heat transfer mechanisms, flow instability and reversal and their effect on heat transfer rates, effect of channel material and surface characteristics (including latest research in coatings), effect of different fluid properties, and its relation to channel material, effect of channel length and aspect ratio. An appreciation of the above can help explain the interpretation of the prevailing fluid flow and heat transfer phenomena and the data scatter and discrepancies observed in past studies. In addition, models and correlations predicting flow patterns and heat transfer rates are presented.

KEYWORDS: Two-phase, boiling, small to micro passages, flow patterns, heat transfer rates, correlations.

\section{INTRODUCTION}

The continuous advances in miniaturization of electronics and high power devices, with significant improvements in their performance, resulted in the generation of huge heat fluxes and thus increased the challenge in the thermal management of these devices. Karayiannis and Mahmoud [1] reported that by 2026, the average heat flux in computer chips is expected to reach $2-4.5 \mathrm{MW} / \mathrm{m}^{2}$ with local hot spots $12-45$ $\mathrm{MW} / \mathrm{m}^{2}$, while in insulated gate bipolar transistors (IGBT) modules the heat flux at the chip level can reach $6.5-50 \mathrm{MW} / \mathrm{m}^{2}$. Accordingly, there is a need for the development of innovative and efficient cooling schemes capable of dissipating high heat fluxes to meet the cooling requirements in the next generations of electronics. Flow boiling in microchannels is one of the most promising cooling schemes that have the potential of dissipating high heat fluxes. For example, Recinella and Kandlikar [2] investigated flow boiling of water in a copper heat sink with radial microchannels $(0.2 \times 0.2 \mathrm{~mm})$ and reported that this heat sink dissipated a heat flux value of $3.69 \mathrm{MW} / \mathrm{m}^{2}$. Drummond et al. [3] investigated flow boiling of HFE-7100 in a hierarchical manifold microchannel array heat sink with channel size (width $\times$ depth) $15 \times 300 \mu \mathrm{m}$. This design dissipated a heat flux value of $9.1 \mathrm{MW} / \mathrm{m}^{2}$. Despite these high heat fluxes, electronics cooling using flow boiling in microchannels is only limited to lab-scale and is not commercially available due to the lack of accurate design equations and the lack of understanding several fundamental issues. These issues include the following: (1) the precise definition of a microchannel and hence design equations to be used, (2) boiling incipience and bubble dynamics, (3) the dominant heat transfer mechanism(s), (4) flow instability, (5) effect of surface microstructure, (6) early dryout and low critical heat flux, (7) prediction of flow patterns, heat transfer rates and pressure drop. The current research group conducted extensive research on flow boiling in single and 
multi-microchannels configurations and studied the effect of several parameters, which can help understand most of the aforementioned fundamental issues. This keynote paper starts with applications of microchannel heat exchangers, reviews fundamental aspects of flow boiling at micro scale and presents new research carried out and published by the current research group.

\section{APPLICATIONS OF MICROCHANNEL HEAT EXCHANGERS}

2.1 Applications The challenge in cooling computer chips arises from the expected huge heat fluxes, which are beyond the capability of conventional cooling techniques. At the same time, the presence of local hot spots may create thermal stresses and thus shorten the life-time of the chip. Flow boiling in microchannels can dissipate high heat fluxes and thus alleviate the effect of hot-spots, i.e. prolong the life-time of the chip. It is well known that the information technology (data centers) is one of the energy intensive industry. Avgerino et al. [5] reported that the IT industry consumes $7 \%$ of the global electricity and this value is predicted to reach $13 \%$ by 2030 while data centers consume $1.4 \%$ of the global electric energy. The same authors reported that the predicted total energy consumption by data centers in Europe will be 104 TWh by 2020 while the value in America will reach $140 \mathrm{TWh}$. It is commonly known that the cooling system in data centers accounts for about $40 \%$ of the total energy consumed by data centers [6]. Assuming that the cost of electricity is $10 \mathrm{cent} / \mathrm{kWh}$, then the cost of electricity in datacenters is expected to reach $\$ 14$ billion by 2020 of which about $\$ 6$ billion will be spent on cooling. An additional advantage of using microchannel heat exchangers for on-chip cooling is that it can play a vital role in energy saving in data centers, with the additional possibility of utilizing the energy recovered.

Miniature vapour compression refrigeration (VCR) systems were introduced as a viable option for electronics and personnel cooling in military and harsh environment. The challenges in the development of miniature VCR for electronics cooling were summarized in ref. [7] as follows: (i) the need for efficient, reliable and compact compressor, (ii) the moisture condensation in the heat sink region, (iii) the cost of the system, (iv) the system should be able to handle variable load and heat dissipation with fast response, (v) the issue of noise and vibration. Microchannel heat exchangers can play an important role in the development of miniature VCR systems because of their capability to provide a high degree of compactness. Some researchers designed and examined the thermal performance of miniature VCR systems with the purpose of electronics cooling. Mongia et al. [8] tested a miniature VCR that incorporates two microchannel evaporators connected in series with cooling capacity of 40 and $10 \mathrm{~W}$ and reported a COP value greater than 2.25 . Thus, the power consumption by the compressor was $22.2 \mathrm{~W}$ ( $44 \%$ of the total cooling load). Wu et al. [9] manufactured a micro compressor for a miniature VCR system with cooling capacity of $300 \mathrm{~W}$ and the measured COP was 2.3. This means that the compressor consumed $130.4 \mathrm{~W}$ (43.5\% of the cooling load). Wu and $\mathrm{Du}$ [10] investigated the effect of refrigerant charge and compressor speed on the performance of a miniature VCR system with cooling capacity of $200 \mathrm{~W}$. Their results indicated that the COP of the system depends on the refrigerant charge and compressor speed and its value varied from 2.7 to 3.4 (the compressor consumes $58.8-74 \mathrm{~W}$ or $29.4-37 \%$ of the cooling load). Yuan et al. [11] investigated the performance of a miniature VCR system for personal cooling applications. Their system achieved a maximum cooling capacity of $260 \mathrm{~W}$ with a COP value of 1.62, i.e. the compressor consumes $160.5 \mathrm{~W}$ (61.7\% of the cooling load). Oliveira and Barbosa [12] tested a VCR system that incorporates a novel two-phase jet heat sink which integrates the evaporator and the expansion device in a single module. They reported that this system dissipated $200 \mathrm{~W}$ with a COP value of about 3 (the compressor consumed $66.7 \mathrm{~W}$ or $33.4 \%$ of the cooling load). It can be concluded from the above studies that the cooling capacity achieved by the examined systems ranged from 50 to $300 \mathrm{~W}$, which is still low compared to the future cooling demand in electronics and high heat flux systems. The above studies agreed on the fact that the compressor is the most challenging component in a miniature vapour compression system, $[9,10]$.

Power electronics such as insulated gate bipolar transistors IGBTs are widely used in several applications such as electric vehicles, rail tractions, wind turbines, power supplies and motors. It is worth mentioning that each module accommodates at least one IGBT chip and one diode chip. Karayiannis and Mahmoud [1] discussed the challenges in the thermal managements of IGBT modules. They concluded that the heat flux at the chip base could be as high as $10-50 \mathrm{MW} / \mathrm{m}^{2}$ for the IGBT chip and $6.3-30 \mathrm{MW} / \mathrm{m}^{2}$ for the diode chip. Thus, the heat flux values at the IGBT chips are much higher than those at the diode chip and consequently the local heat fluxes are not uniformly distributed inside the module, which may result in severe temperature gradients in the substrate. Accordingly, the cooling system of IGBT modules should take into account the non-uniform 
heat flux distribution inside the module, which still is challenging. Although liquid cooled IGBT modules are commercially available, overheating is still the main reason of failure in IGBT modules. Thermo-mechanical stresses were reported as the main reason of failure in IGBTs [13]. As previously mentioned, two phase flow boiling in microchannels could be very efficient in cooling IGBT modules due to the capability of reducing the hot spots inside the chip and achieving high heat transfer rates. Saums et al. [14] evaluated experimentally the cooling of IGBT modules using air, water and R134a refrigerant. They concluded that two phase cooling using R134a achieved much higher heat dissipation rates, e.g. the heat dissipation rate increased by $96 \%$ compared to water cooling and increased by $125 \%$ compared to air cooling. Additionally, it achieved significant reduction in size and weight, e.g. the size of the cooling system decreased by $250 \%$.

The polymer electrolyte membrane (PEM) fuel cells are widely used in the auto industry due to their fast start up and low operating temperature (about $80{ }^{\circ} \mathrm{C}$ ). The challenge in the thermal management of PEM fuel cells arises from the fact that the temperature of the cell varies considerably, which is expected to affect the cell performance and membrane life-time [15]. Another challenge arises from the low operating temperature, i.e. small temperature difference between the cell and the ambient. This requires huge heat transfer surface area to dissipate the generated heat effectively, which can be achieved with microchannel heat exchangers. Additionally, the cell operating temperature should be maintained within a certain range. Barreras et al. [16] reported that if the cell temperature is too low, water will flood and prevent the transport of the reactant gases through the membrane. If the cell temperature is too high, the membrane will be dehydrated and thus performance degradation will occur. In fuel cells, the most important sources of heat generation are the irreversibility of electrochemical reactions and joule heating [17] and thus the conversion efficiency in PEM fuel cells was about $50 \%$ [18]. Another complexity in fuel cells is the variation of heat dissipation with the cell voltage. Pandiyan et al. [17] reported that with $16.7 \%$ reduction in the cell voltage (from 0.6 to $0.5 \mathrm{~V}$ ), the conversion efficiency decreased from $50 \%$ to $33 \%$. In other words, the heat dissipation rate increased significantly as the cell voltage decreased. Pei et al. [19] measured the temperature distribution in the cathode plate of a PEM fuel cell stack that was cooled with de-ionized water. It was found that the temperature peaks at the cells located at the middle of the stack with a maximum temperature difference of $8 \mathrm{~K}$. The currently adopted research attempts of cooling PEM fuel cells include single phase liquid cooling using nanofluids [20, 21] and heat pipes $[22,23]$. Although boiling in microchannels is very promising for thermal management of PEM fuel cells, there is limited research on boiling in microchannels at conditions relevant to fuel cell applications. One of the recommended fluids could be HFE-7100 and FC-72, which have a saturation temperature of $61{ }^{\circ} \mathrm{C}$ and $56{ }^{\circ} \mathrm{C}$ at atmospheric pressure. They can achieve cell temperature of about $75{ }^{\circ} \mathrm{C}$ with the assumption that the wall superheat is about $10-15 \mathrm{~K}$.

2.2 Cost Effectiveness of Using Two-phase Flow Pumped Systems Some researchers reported on the effectiveness of pumped systems incorporating microchannels heat exchangers (the fluid is driven by a small pump) compared to other cooling systems. For example, Berkeley and Mahdavi [24] presented a case study for comparison between conventional air cooling and on-chip water cooling for a small supercomputer (300 $\mathrm{kW})$. It was found that the conventional chilled air cooling system consumed $44 \%$ of the rated power $(0.44 \times$ $300 \mathrm{~kW})$ while the direct on-chip water cooling consumed $16.7 \%(0.167 \times 300 \mathrm{~kW})$. With the fact that flow boiling heat transfer coefficient is much higher than that of single phase flow, more energy saving can be achieved with boiling in microchannels. Marcinichen et al. [25] conducted an evaluation study for three cooling systems to cool a server blade with total power $3.7 \mathrm{~kW}$. The first system was single phase water cooling, the second system was two phase pumped loop cooling system using R134a and R1234ze and the third system was vapour compression cycle (VCC). They found that the power consumption by the two phase pumped system was the lowest, i.e. $6.4 \mathrm{~W}$ for R134a and $7.9 \mathrm{~W}$ for R1234ze. On the contrary, the single phase water cooling consumed $35 \mathrm{~W}$ and the VCC consumed 746.5 W. In other words, the two phase pumped system is more efficient compared to vapour compression refrigeration systems (compressor-based systems). In the experimental work of Al-Zaidi et al. [26], for a multichannel evaporator consisting of rectangular channels of hydraulic diameter $0.46 \mathrm{~mm}, 20 \mathrm{~mm}$ long and using HFE-7100, the recorded energy consumption of the microgeared pump at the highest heat flux of $335.29 \mathrm{~kW} / \mathrm{m}^{2}(167.6 \mathrm{~W}$ of cooling) was $14.25 \mathrm{~W}$. This indicates the possible low pumping power of these integrated systems. The COP) of such a system is 11.8, which is much higher that the small scale refrigeration systems mentioned above. Mahmoud and Karayiannis [27] evaluated experimentally the performance of a small scale pumped loop cooling system using HFE-7100 in a multimicrochannel evaporator and reported a COP value of 22.1 at $384 \mathrm{~W}$ cooling load. As mentioned above, an additional advantage of the pumped systems is the possible energy recovery in applications such as data centres. 
One of the challenges in both pumped two-phase flow systems and small scale refrigeration systems is the design of the condenser [28], which is currently assessed by the present authors. This can be considerably larger than the microscale evaporator, especially if the final heat sink is the ambient air.

\section{DEFINITION OF SMALL TO MICRO PASSAGES}

The precise definition of a microchannel and/or the criterion used to distinguish between macro and micro heat exchangers is still a controversial issue among researchers. Shah and Sekulic [29] defined microchannels based on the surface to volume ratio $(\beta)$. Heat exchangers were regarded as compact for $\beta \geq 700 \mathrm{~m}^{2} / \mathrm{m}^{3}$, meso for $\beta$ $\geq 3000 \mathrm{~m}^{2} / \mathrm{m}^{3}$, and micro for $\beta \geq 15000 \mathrm{~m}^{2} / \mathrm{m}^{3}$. Some researchers [30,31] used a fixed range of diameter for the definition of a microchannel. For example, Mehendale et al. [30] considered heat exchangers as conventional for $D>6 \mathrm{~mm}$, compact for $D=1-6 \mathrm{~mm}$, meso for $D=0.1-1 \mathrm{~mm}$ and micro for $D=0.001-$ $0.1 \mathrm{~mm}$. Kandlikar and Grande [31] defined heat exchangers as conventional for $D>3 \mathrm{~mm}$, mini for $D=0.2$ $-3 \mathrm{~mm}$ and micro for $D=0.01-0.2 \mathrm{~mm}$. This classification did not take into account the effect of flow and fluid properties on bubble size and confinement and may not be representative for two phase flow. Hence, some researchers studied the effect of channel size and flow rates on flow patterns and reported significant effects on flow patterns characteristics. These effects were attributed to the relative importance of the gravity, surface tension and inertia forces. Therefore, they proposed non-dimensional criteria for the transition from macro to micro scale, which took into consideration the effect of gravity, inertia and surface tension forces. The important dimensionless groups included the Eotvos number [32, 33], the confinement number [34], the Bond number [35], the Laplace constant [36] and the Reynolds number [37], see Karayiannis and Mahmoud [1] for more details. Karayiannis and Mahmoud [1] evaluated the criteria, based on the dimensionless groups, using water, R134a, R245fa, R236fa and HFE-7100 and reported clear discrepancy with some partial agreement among some criteria as seen in Fig. 1, [1]. The values predicted by the criterion given by Harirchian and Garimella [37] agree with those predicted by the second criterion (c2) given by Tibirica and Ribatski [38]. Chen et al. [39] investigated flow boiling patterns for R134a in four vertical metallic tubes with $\mathrm{D}=4.26,2.88$, 2.01 and $1.1 \mathrm{~mm}$. They reported that confined bubble flow (a characteristic of small tube) appeared at some operating conditions in the $2.01 \mathrm{~mm}$ tube and was established at all conditions in the $1.1 \mathrm{~mm}$ diameter tube. Thus, it was concluded that the threshold diameter between small and conventional tubes may be of the order of $2 \mathrm{~mm}$. This value agrees with the value predicted by the first criterion (c1) given by Tibirica and Ribatski [38] and the criterion given by Ong and Thome [40] and is near to the values given by the criterion of Cornwell and Kew [34]. It is obvious from Fig. 1 that some criteria demonstrate small dependence on the saturation temperature, while others indicate a strong dependence. Recent flow visualisation work by the present group with R134a indicates two possible transition points, i.e. from traditional to small or mini and small to micro. However and in conclusion, a comprehensive definition that considers the fundamental phenomena and mechanism(s) is required to classify normal, small and micro size tubes. More experimental data that consider a wide range of diameters and different fluids are necessary.

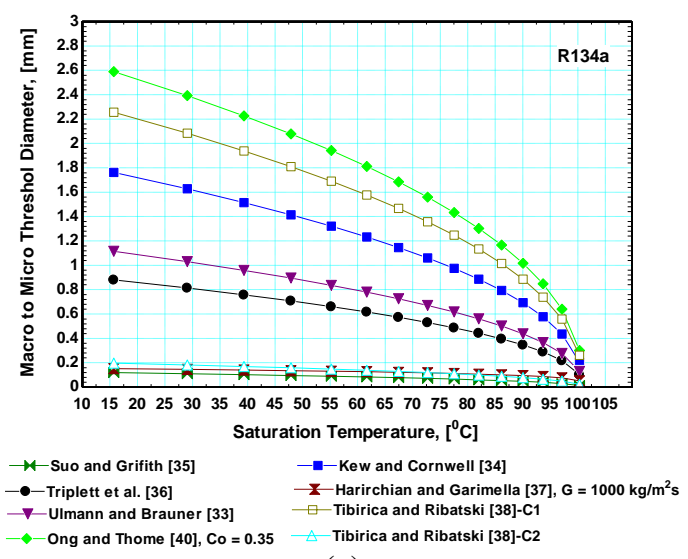

(a)

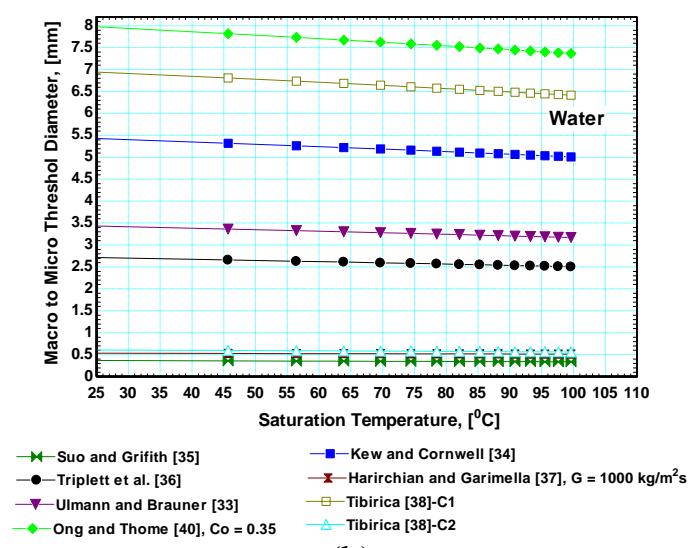

(b)

Fig. 1. The effect of saturation temperature on the threshold value for R134a (a) and water (b) [1]. 


\section{NUCLEATION IN CONFINED SPACES}

Nucleation in microchannels may exhibit complex behaviour compared to that occurring in large diameter channels. The complexity can arise from the small size and/or very smooth boiling surface due to the manufacturing processes, i.e. few nucleation sites. As a result, nucleation may occur at high wall superheat and high heat fluxes compared to large diameter channels, which could result in explosive boiling and significant effects on local heat transfer rates and mechanism(s). For example, Yen et al. [41] reported wall superheat value of $100 \mathrm{~K}$ and $45 \mathrm{~K}$ at boiling incipience for $\mathrm{D}=0.19 \mathrm{~mm}$ and $\mathrm{D}=0.51 \mathrm{~mm}$, respectively. Peng et al. [42] reported peculiar behaviour for boiling in microchannels and did not observe any bubbles in their experiment, although the boiling curve exhibited fully developed nucleate boiling behaviour. Hence, they called this phenomenon "fictitious boiling" and proposed the concept of "minimum evaporating space" to explain this unique behaviour. Additionally, based on a model proposed by [42], they concluded that: (i) wall superheat at boiling incipience increases as the diameter decreases and (ii) fluids with greater liquid to vapour density ratio, higher latent heat and larger thermal diffusivity require larger heat fluxes at boiling incipience. Ghiaasiaan and Chedester [43] reported that nucleation in microchannels is significantly affected by the thermo-capillary force and the drag force acting on a nucleating bubble. They proposed a model for nucleation which predicts that nucleation is suppressed when the thermo-capillary force overcomes the drag force. Lee et al. [44] reported that channel height has a significant effect on bubble nucleation in microchannels, while heat and mass flux have insignificant effects. As the channel height decreases, the critical cavity radius decreases. $\mathrm{Li}$ and Peterson [45] investigated nucleation in a trapezoidal microchannel with a very smooth surface $(R a=$ $0.005 \mu \mathrm{m}$ ) using de-ionized water as the test fluid. It was found that the heat flux and wall superheat at boiling incipience were $43 \mathrm{MW} / \mathrm{m}^{2}$ and $110 \mathrm{~K}$, respectively. They attributed the nucleation mechanism to vapour explosion on a smooth surface rather than nucleation from surface cavities. The Hsu [46] model (Eq. (1) below applied with these conditions by the present authors, predicts a range of active cavity sizes of $0.25-6.3 \mu \mathrm{m}$. This is significantly larger than the average roughness of the channel $(0.005 \mu \mathrm{m})$. Furthermore, using the model gives a heat flux value at boiling incipience of $38 \mathrm{MW} / \mathrm{m}^{2}$, which is $13 \%$ lower than the measured value of 43 $\mathrm{MW} / \mathrm{m}^{2}$. This reasonable predictions of the heat flux at boiling incipience could be indicative that the model can be used in microchannels. The average roughness gives an indication of the average depth of the cavities but not the cavity mouth radius, which is predicted by the Hsu [46] model. Hence the difference between the predicted minimum cavity size $(0.25 \mu \mathrm{m})$ and the average surface roughness $(0.005 \mu \mathrm{m})$ may indicate that the average surface roughness is not a suitable parameter for characterizing the surface in terms of size of active nucleation sites. Note that not all researchers report such large superheat values at boiling incipience. For example, Wang and Cheng [47] investigated boiling incipience for de-ionized water in a silicon micro channel with $R a$ value of $0.05 \mu \mathrm{m}$. It was reported that nucleation occurred at a wall superheat value of $40 \mathrm{~K}$ and heat flux $3.31 \mathrm{MW} / \mathrm{m}^{2}$. The researchers claimed heterogeneous nucleation on a smooth surface free of cavities. The predicted range of an active cavity using the Hsu model for the values of wall superheat in [47] is $0.68-17.5$ $\mu \mathrm{m}$. This, again did not match the Ra value of $0.05 \mu \mathrm{m}$. In addition, the predicted heat flux at boiling incipience is $5 \mathrm{MW} / \mathrm{m}^{2}$, which is $33.8 \%$ higher than the measured value of $3.31 \mathrm{MW} / \mathrm{m}^{2}$. It can be concluded from the above studies that high wall superheat/heat flux is required at boiling incipience, the thermo-capillary force and channel height affect nucleation considerably, the Hsu model performs reasonably in microchannels and the average surface roughness is not the correct surface parameter for estimating the cavity mouth radius and hence the heat flux and degree of superheat for ebullition.

$$
r_{c}(\max , \min )=\frac{\delta_{t}}{4} \frac{\Delta T_{\text {sup }}}{\left(\Delta T_{\text {sup }}+\Delta T_{\text {sub }}\right)}\left[1 \pm \sqrt{1-\frac{12.8 \sigma T_{\text {sat }}\left(\Delta T_{\text {sup }}+\Delta T_{\text {sub }}\right)}{\delta_{t} \rho_{g} h_{f g} \Delta T_{\text {sup }}{ }^{2}}}\right]
$$

Mahmoud and Karayiannis [4] assessed the effect of fluid type (fluid properties) on the size range of active nucleation sites using the above equation, see Fig. 2. According to Eq. (1), as the surface tension increases, the required minimum cavity radius increases, i.e. rough surfaces are preferred for bubble nucleation. However, as the vapour density and latent heat increases, the required minimum cavity radius decreases (smoother surfaces, i.e. smaller cavities, can provide nucleation sites). Hence, the surface tension and the term $\rho_{g} h_{f g}$ have two opposite effects. Note that R134a has low surface tension and high $\rho_{g} h_{f g}$ compared to fluids like R245fa ethanol or water examined here. This means that nucleation is possible with R134a from surfaces 
with small size cavities (nano/micro-structure) compared to the other fluids studied. In addition to the above, the following can be concluded from Fig. 2: (1) The minimum cavity radius decreases as the wall superheat increases, i.e. cavities of smaller size become active. (2) The minimum wall superheat corresponding to the critical cavity radius was $0.013 \mathrm{~K}, 0.081 \mathrm{~K}, 1.3 \mathrm{~K}$ and $9.8 \mathrm{~K}$ respectively for R134a, R245fa, ethanol and water. (3) The range of active cavity sizes decreases as the surface tension increases and/or the term $\rho_{g} h_{f g}$ decreases.This is seen in the results of R134a (wide range) compared to for example water (narrow range). (4) At the saturation temperature $39.4{ }^{\circ} \mathrm{C}$ examined, water required rough surfaces compared to refrigerants. Note that the saturation pressure corresponding to $39.4{ }^{\circ} \mathrm{C}$ is 0.074 bar for water and is $0.174 \mathrm{bar}$ for ethanol and the nucleation superheat is very large compared to refrigerants at the same conditions, especially for water. As depicted in Fig. $2 b$ the required wall superheat for water at atmospheric pressure is significantly low compared to the case of 0.074 bar. Hence the results demonstrate also that the range of active nucleation sites increases and nucleation shifts to cavities of smaller size as the system pressure increases. This indicates that water under vacuum is not a good choice for cooling high heat flux devices due to the required high wall superheat at boiling incipience compared to other fluids examined her. Therefore water may not be suitable for cooling devices that require surface temperature below $85^{\circ} \mathrm{C}$. From the above analysis, it can also be clearly stated that the surface characteristics should be considered in relation to fluid properties, since relatively smooth surfaces can perform better with refrigerants compared to high surface tension fluids such as water.

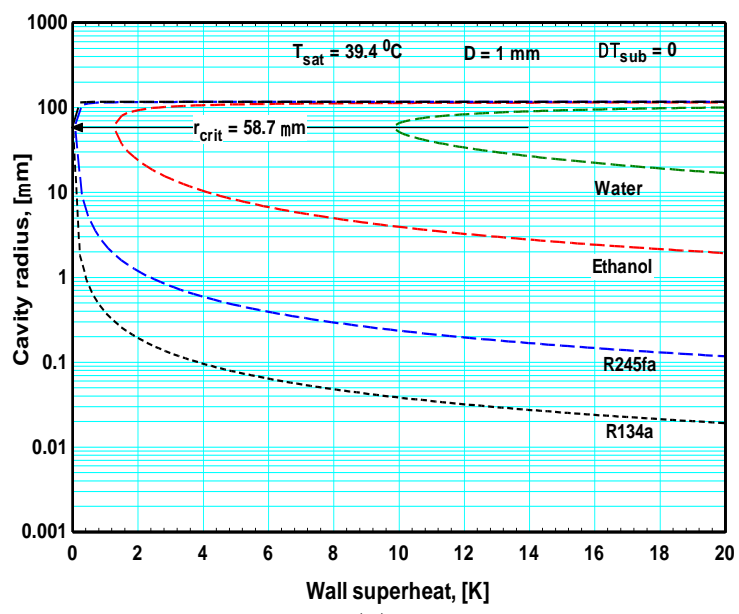

(a)

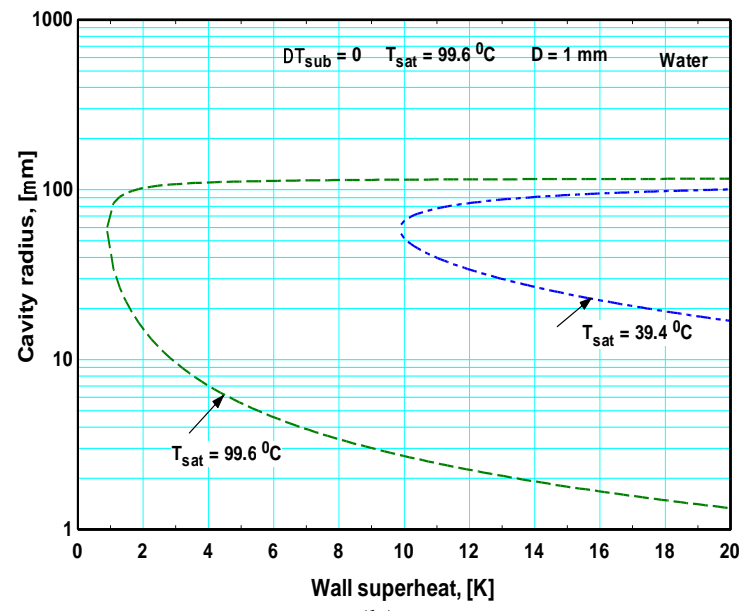

(b)

Fig. 2. The range of active nucleation sites predicted using the Hsu [46] model, (a) effect of the type of fluid, (b) effect of saturation temperature for water, [4].

\section{BUBBLE DYNAMICS - EFFECT OF CONFINEMENT}

In pool boiling, it is commonly known that, two forces are deemed important in bubble growth and departure cycle namely; surface tension and buoyancy forces. Additionally, bubble growth is controlled by inertia in the early stage $\left(R_{b} \alpha t\right)$ [48] while in a later stage it is controlled by the heat transfer rate at the bubble wall $\left(R_{b} \alpha\right.$ $\left.t^{0.5}\right)$ [49]. In conventional flow boiling systems, the bubble dynamics may exhibit different characteristics compared to pool boiling due to the effect of other forces arising from the fluid motion. The bubble leaves the nucleation site either by sliding motion along the heated surface or by lifting-off the surface while in pool boiling the sliding motion is very rare. In microchannels, bubble confinement may result in a complex behavior compared to pool boiling and large diameter channels. This section sheds some light on the features of bubble dynamics in microchannels reported by a number of researchers. Lee et al. [50] observed that the bubble grows and stretches in the flow direction and hence forms a balloon-like shape with a stretched neck and remains anchored at the nucleation site. At the moment of departure, the liquid/vapour interface at the neck merges immediately. Lee et al. [51] reported similar behaviour and attributed the non-spherical shape of the bubble to the effect of drag force and the restricted channel size. They concluded the following: (i) the bubble diameter increased almost linearly with time (inertia controlled bubble growth), (ii) the surface temperature does not affect the bubble departure volume but it affects the evaporation rate (growth rate), which contradicts the macro scale systems where the bubble departure volume increases with increasing surface temperature, (iii) the bubble departure volume increases as Reynolds number decreases (drag force was considered as the dominant 
force affecting bubble departure) and (iv) bubble departure volume increases as the channel height increases. It is worth mentioning that Lee et al. [44] reported that there was no waiting period, i.e. there was no time delay between the old bubble and the formation of a new one. Lee et al. [51] observed that bubbles nucleate at the channel corners at a number of locations along the channel and the bubble grew almost linearly with time $(R \alpha t)$, indicating that the process of bubble growth is inertia controlled. Also, it was reported that surface tension and drag forces are the most dominant forces affecting bubble departure size in microchannels. Lee et al. [52] investigated the effect of creating artificial nucleation sites on bubble nucleation and dynamics in a single microchannel. It was found that for channels without artificial nucleation site, the wall superheat affected the bubble dynamics strongly. At wall superheat of $4 \mathrm{~K}$, the bubbles took $70 \mathrm{~ms}$ to grow to the channel width before departure while at wall superheat of $6 \mathrm{~K}$ the bubble grew in an explosive manner and took only $2 \mathrm{~ms}$ to reach the channel size. For the channel with artificial nucleation site, the bubble grew to the channel size and expanded without detachment in both upstream and downstream directions. Additionally, the bubble grew according to the relation $R \alpha t^{3}$, which is different compared to bubble growth in pool boiling $\left(R \alpha t^{0.5}\right)$. Yin et al. [53] observed that the bubble nucleates at the channel corner then it departs the nucleation site by sliding motion along the channel. The bubble size and sliding velocity did not change significantly in the early stage of sliding while at a later stage, immediately before lifting off, the sliding velocity was larger and the bubble size was smaller. This sliding motion was attributed to a balance between the quasi steady drag and surface tension forces.

Mahmoud and Karayiannis [4] used the model proposed by Klausner et al. [54] for the prediction of bubble departure diameter in flow boiling systems to quantify the effect of fluid properties, tube diameter and operating conditions (saturation temperature and mass flux) on the bubble dynamics. The details of the equations are summarized in ref. [4] and the results of evaluation are depicted in Fig. 3 for saturation temperature $39.4{ }^{\circ} \mathrm{C}$. It was found that the bubble growth rate of $\mathrm{R} 245 \mathrm{fa}$ is significantly higher than that of $\mathrm{R} 134 \mathrm{a}$ but considerably lower than that of ethanol and water. They assumed that the waiting period is negligible and thus the bubble generation frequency can be estimated directly from the bubble growth time. On doing so, the frequency was 91 bubbles/sec for R245fa, 8 bubbles/sec for R134a, 10869 bubbles/sec for ethanol and 23810 bubbles/sec for water. Accordingly, they reported that at the exit of the heated tube, bubbly flow is more likely with R134a due to the low bubble generation frequency and thus low bubble coalescence rate. On the contrary, slug or churn flow is expected with R245fa immediately at boiling incipience due to the relatively high bubble generation frequency and the expected high coalescence rate. For water and ethanol, due to the very high bubble generation frequency, bubbly and even slug flow patterns are rarely observed (annular flow is the dominant flow regime). Mahmoud and Karayiannis [4] compared the thermo-physical properties of the four fluids and concluded that: (i) there is a small difference in latent heat, liquid specific heat and liquid thermal conductivity between the two refrigerants. (ii) the liquid to vapour density and viscosity ratio and surface tension show variation and have a significant effect on bubble growth and departure. In other words, for refrigerants, as the surface tension and liquid to vapour density and viscosity ratio increases, the bubble growth rate increases. For water and ethanol there was a big difference in all properties which makes it difficult to estimate which parameter is important. Figure 3 depicts an interesting point, i.e. that the bubble departure radius ranged from 60 to $65 \mu \mathrm{m}$ (bubble diameter $120-130 \mu \mathrm{m}$ ) for all fluids. Bearing in mind that the bubble departure frequency depends significantly on fluid properties, the flow patterns are expected to be different as discussed above although the departure size is nearly the same. In other words, bubble generation frequency is the most important factor in the evolution of flow patterns. Figure $3 \mathrm{c}$ demonstrates that as the pressure increases, the bubble growth time increases and consequently the bubble generation frequency decreases. It can be concluded from the above studies that bubble growth in microchannels is different compared macro channels and channel height was reported to affect the bubble departure size. Surface tension and drag forces affect significantly the bubble growth and departure in microchannels. Fluid properties did not affect significantly the bubble departure size, i.e. bubble departure is more controlled by the forces due to fluid motion. On the contrary, the bubble growth time (bubble generation frequency) depends significantly on fluid properties. Thus, the flow patterns in flow boiling are more influenced by the bubble generation frequency rather than the bubble departure size. 


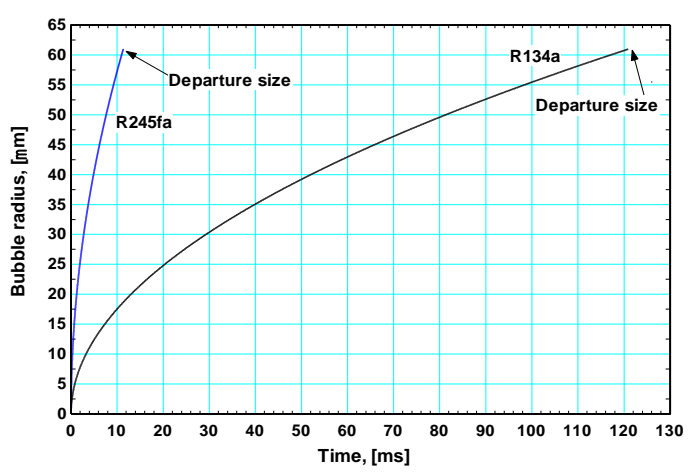

(a)

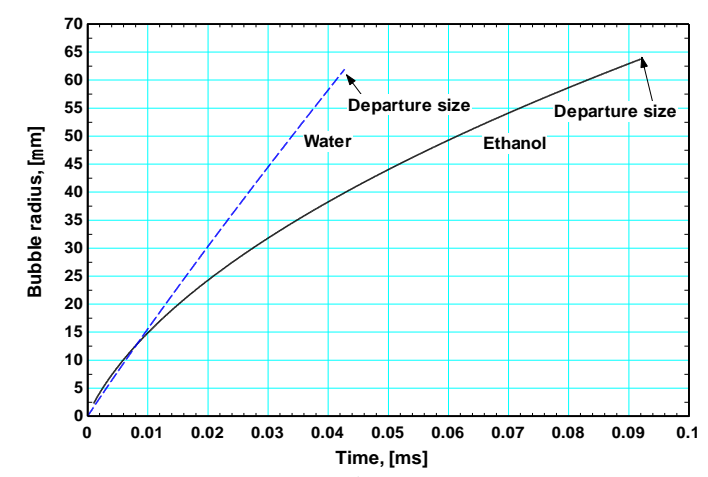

(b)

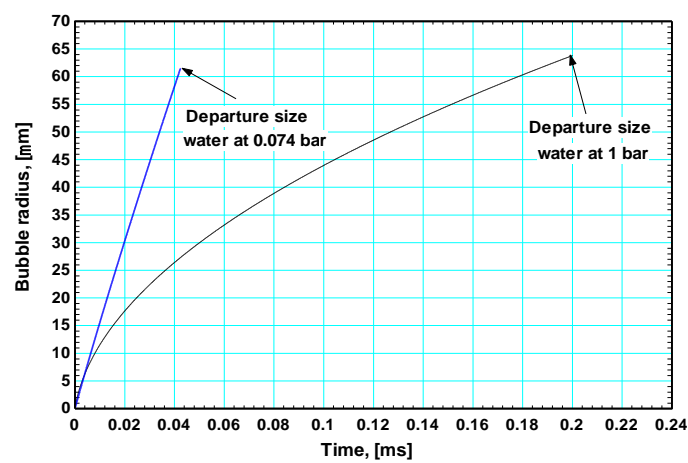

(c)

Fig. 3. Effect of fluid type and saturation pressure on the bubble growth rate and departure radius [4] predicted using the force balance model of Klausner et al. [54], (a) R245fa versus R134a, (b) ethanol versus water, (c) effect of saturation pressure for water.

\section{EFFECT OF SURFACE CHARACTERISTICS}

6.1 Effect of Surface Manufacturing Method The method of manufacturing the test channel for flow boiling systems could result in significant variations in the surface micro structure and consequently variations in the local heat transfer rates and mechanism(s). Indeed, the effect of surface structure on flow boiling heat transfer rates is difficult to understand because the variations in surface structure may also result in variations in the surface wettability [55, 56]. Some researchers [57-59] investigated the effect of surface roughness on flow boiling heat transfer rates in mini and microchannels and reported different conclusions. Kandlikar and Spiesman [57] reported that surface roughness had an insignificant effect on the heat transfer rates. Jones and Garimella [58] concluded that surface roughness did not affect boiling incipience but affected the critical heat flux (CHF) especially at low mass fluxes. The rough surface in their study achieved enhancement in CHF of $22 \%$. Alam et al. [59] observed that as the surface roughness increases, the active nucleation site density increases, the heat transfer rate increases and the wall superheat at boiling incipience decreases. The current research group studied the effect of the method of manufacturing tubes on local flow boiling heat transfer rates, see Mahmoud et al. [60]. They tested two stainless steel tubes of diameter $1.1 \mathrm{~mm}$ and $150 \mathrm{~mm}$ heated length using R134a as the test fluid. The first tube was manufactured by the welding method while the second tube was manufactured by the cold drawn process. They characterized the inner surface using Scanning Electron Microscope (SEM) analysis and the results are shown in Fig. 4. The figure demonstrated that the surface of the welded tube is smooth with few debris of irregular shape, and nucleation will depend on whether this shape forms a cavity-like structure or not. On the contrary, for the cold drawn tube, many longitudinal scratches that seem uniformly distributed along the surface were found. The difference in surface microstructure resulted in a clear difference in the trend of the local heat transfer coefficient versus local vapour quality as seen in Fig. 5. For the welded tube, the heat transfer coefficient jumped to a peak value at vapour quality near zero then decreased rapidly to a minimum value after which it increased rapidly with vapour quality before it decreases again at the last thermocouple location. The heat flux effect was very complex. For the cold drawn tube, the heat transfer coefficient peaked at quality values very close to zero then it remained approximately constant with local quality with a clear heat flux effect. 


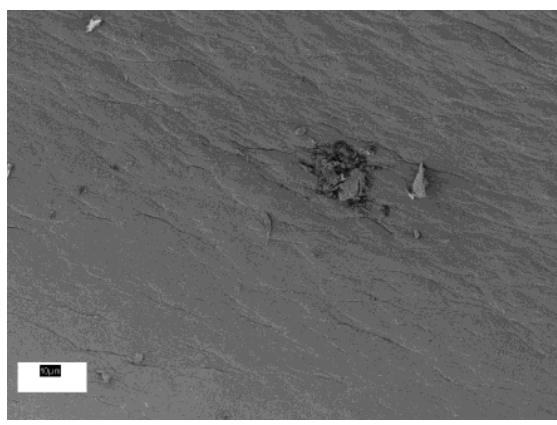

(a)

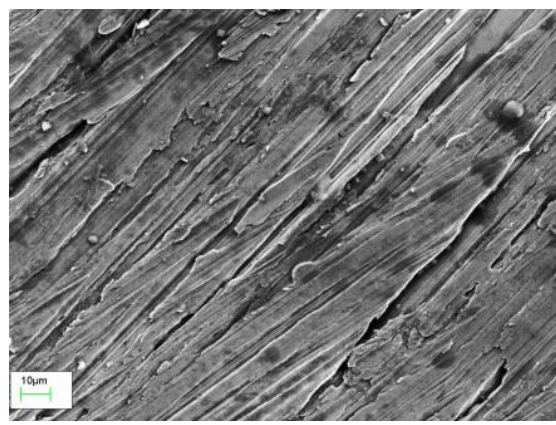

(b)

Fig. 4. SEM images for the inner surface of (a) welded tube of $1.16 \mathrm{~mm}$ diameter and (b) seamless cold drawn tube of $1.1 \mathrm{~mm}$ diameter, Mahmoud et al. [60].

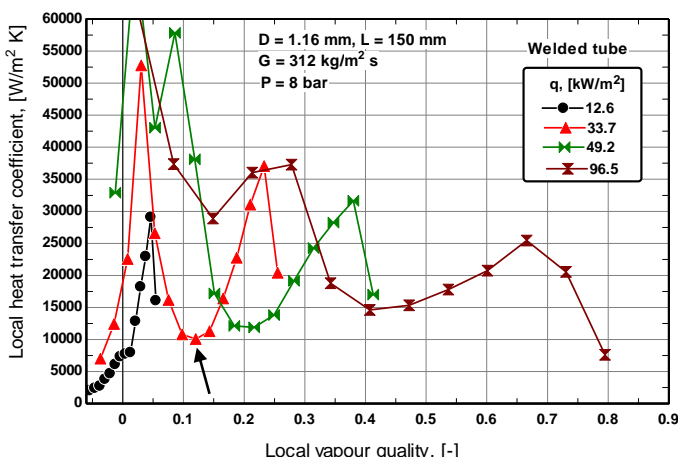

(a)

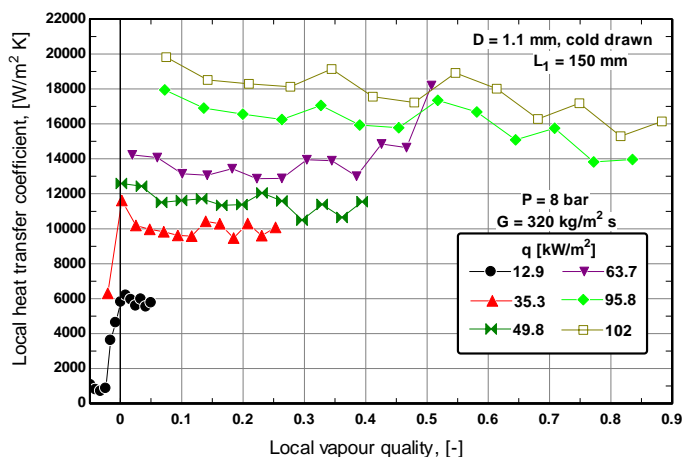

(b)

Fig. 5. Local heat transfer coefficient versus local vapour quality at pressure 8 bar and mass flux 300 $\mathrm{kg} / \mathrm{m}^{2} \mathrm{~s}$, (a) welded tube, (b) seamless cold drawn tube, adapted from Mahmoud et al. [60].

Mahmoud et al. [60] observed that the wall superheat at boiling incipience reached $17.4 \mathrm{~K}$ in the welded tube and $3.7 \mathrm{~K}$ in the cold drawn tube, see Fig. 6 and was considered as a reason for the peculiar trend of heat transfer coefficient in the welded tube. The high superheat results in rapid bubble growth and thus the elongated bubble regime may appear immediately at boiling incipience. Additionally, the bubble may grow while it remains anchored to the nucleation site for a while and hence a dry area can form around the elongated bubble. This may explain the high heat transfer coefficient at vapour quality near zero and the rapid decrease with quality when the dry area forms around part of the bubble. When the bubble leaves the nucleation site and moves with the flow, the liquid film was reconstructed around the bubble and due to the scarcity of nucleation sites in the welded tube, liquid film evaporation becomes more dominant. This may be inferred from the rapid increase in heat transfer coefficient with vapour quality after the minima in Fig. 5a (see arrow in figure for $\mathrm{q}=34 \mathrm{~kW} / \mathrm{m}^{2}$ as example), which was not observed in the cold drawn tube (tube that was thought to have more nucleation sites). Mahmoud and Karayiannis [4] attributed the absence of the increasing trend with quality in the cold drawn tube to possible partial nucleation in the liquid film in annular flow, which may disturb the liquid film. They compared the experimental data of the two tubes with predictions from Cooper [61] pool boiling correlation and annular flow models (assuming liquid film evaporation), see Fig. 7. The figure demonstrated that the data of the cold drawn tube agree very well with the Cooper correlation indicating possible contribution of nucleate boiling. By contrast, there were significant deviations between the data of the welded tube and the predictions from the Cooper correlation, e.g. the heat transfer coefficient increased rapidly with increasing vapour quality. In other words, the contribution of nucleation mechanism was very small in the welded tube (smooth surface). The comparison with the annular flow models [62-64] (models that assume convective film evaporation as a dominant mechanism) indicated that the trend in the welded tube agrees well with the predictions based on the Ishii [62] and Cioncolini and Thome [63] models. Finally, they concluded that the presence of nucleation in annular flow may cause the heat transfer coefficient fluctuation with vapour quality due to disturbance in the liquid film and possible periodic local dryout, which makes the time averaged heat transfer coefficient nearly constant with vapour quality. 


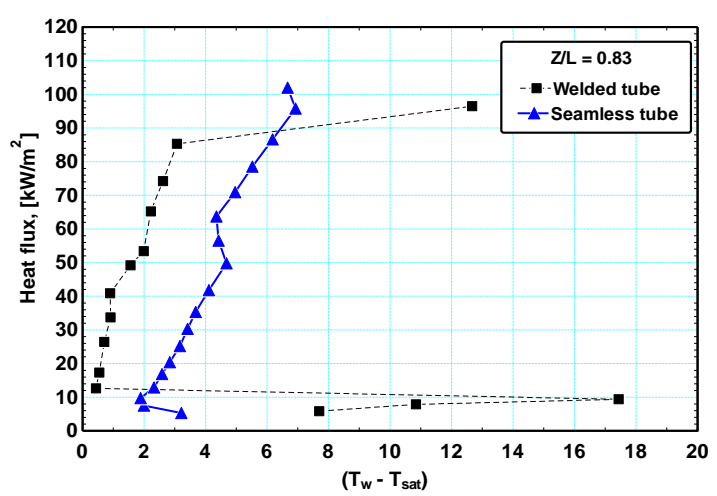

Fig. 6. The boiling curves for the welded and seamless tube, Mahmoud et al. [60]

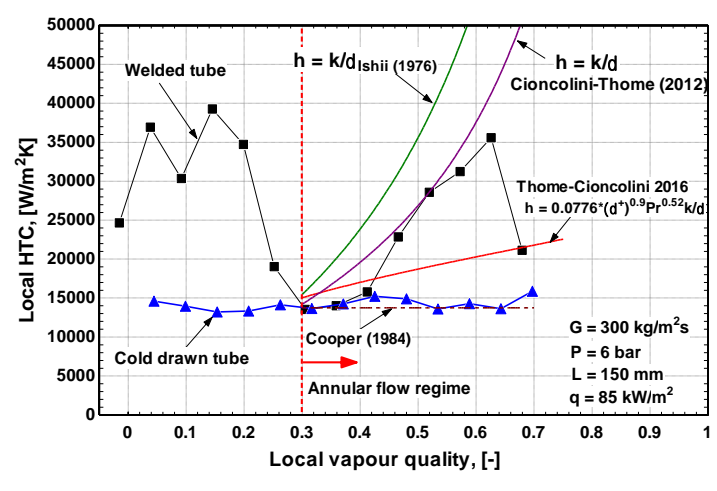

Fig. 7. The local heat transfer coefficient in the welded and cold drawn tube compared with some prediction methods in annular flow [4].

6.2 Effect of Surface Coating Heat transfer enhancement in flow boiling by surface coating has attracted the attention of many researchers in the recent years. Ammerman and You [65] investigated flow boiling of FC-87 in a silicon channel $(2 \times 2 \mathrm{~mm})$ coated with a $100 \mu \mathrm{m}$ layer of a micro porous coating. They reported that the heat transfer coefficient was enhanced by $140-200 \%$ (the upper value corresponds to the lowest mass flux and the lower value corresponds to the higher mass flux) and the CHF by $14-36 \%$. Yang et al. [66] studied flow boiling of HFE7000 in silicon multi- microchannels $(250 \times 220 \mu \mathrm{m})$ coated with Si nano wires (Si-NWs coating). It was observed that bubbly and slug flow did not appear in the coated channels and annular flow was the dominant flow regime. The absence of bubbly and slug flow in the coated channels was attributed to the dominance of capillary force at the porous surface, which holds the liquid film on the boiling surface. Additionally, the average heat transfer coefficient in the coated channels was enhanced by $344 \%$, especially at low mass flux and vapour quality. The enhancements decreased to a $104 \%$ at high vapour quality near the CHF. Khanikar et al. [67] tested flow boiling of water in a rectangular channel $(0.371 \times 10 \mathrm{~mm})$ coated with carbon nanotubes (CNTs). It was found that the CNT-coated surface enhanced the CHF by about 21-23 $\%$ at low mass flux $\left(86 \mathrm{~kg} / \mathrm{m}^{2} \mathrm{~s}\right)$ while the CHF decreased by $1-21 \%$ at high mass flux $\left(228 \mathrm{~kg} / \mathrm{m}^{2} \mathrm{~s}\right)$. The authors stated that the physical changes in the morphology of the CNTs induced by the high flow velocity, e.g. bending of the nano-tubes, can explain the degradation at high mass flux. Morshed et al. [68] studied water flow boiling in a rectangular channel $(0.372 \times 5 \mathrm{~mm})$ coated with $\mathrm{Cu}-\mathrm{Al}_{2} \mathrm{O}_{3}$ composite nano particles. It was reported that the incipience wall superheat decreased by $5.5 \%$ for the coated surface while the average heat transfer coefficient was enhanced by $30-50 \%$ at low mass flux and $35-120 \%$ at high mass flux. Additionally, the CHF was enhanced by 35 to $55 \%$, which was attributed to the decrease in contact angle or increase in surface wettability. Kim et al. [69] examined water flow boiling in a channel coated with a "smart coating", i.e. the wettability changes spontaneously with the changes in wall superheat. The surface changes from hydrophobic at low wall superheat to hydrophilic at high wall superheat. It was found that boiling started at lower wall superheat for the smart surface with the observation of several active nucleation sites compared to the uncoated surface. This was attributed to the effect of surface wettability, which was considered the most significant factor. Additionally, the smart surface enhanced the heat transfer coefficient by $109 \%$ but it did not affect the CHF. Bai et al. [70] investigated flow boiling of ethanol in porous-coated multi microchannel copper heat sinks. It was found that the wall superheat at the onset of boiling was about $17 \%$ lower for the coated channels compared to the uncoated ones. Additionally, they concluded that the enhancement in heat transfer coefficient due to coating was very limited to the low vapour quality region $<0.2$ (low heat flux levels).

Kaya et al. [71] tested flow boiling in stainless steel tubes of diameter $0.249,0.507$ and $0.998 \mathrm{~mm}$ which were coated with a $30 \mathrm{~nm}$ layer of a polymer with water. It was found that the CHF increased by $17 \%, 24 \%$ and $8 \%$ respectively for $\mathrm{D}=0.249,0.509,0.998 \mathrm{~mm}$ at the lowest mass flux while at the highest mass flux the enhancement was $18 \%, 22 \%$ and $17 \%$ in the same order. The authors explained that the decrease in the contact angle due to the coating (better wettability) from $75^{\circ}$ for the plain surface to $45^{0}$ for the coated surface causes the enhancement in CHF. At the lowest mass flux, the heat transfer coefficient of the coated tubes (measured at one location near the tube exit) increased by $109 \%, 26 \%$ and $22 \%$ respectively for $\mathrm{D}=0.249,0.507$ and $0.998 \mathrm{~mm}$ compared to the uncoated tube. At the highest mass flux the corresponding values were: $104 \%$, $55 \%$, and $19 \%$. Nedaei et al. [72] extended the work by Kaya et al. [71] and coated the $0.507 \mathrm{~mm}$ diameter tube such that the surface wettability (contact angle) can be different along the tube length, i.e. wettability gradient in the axial direction. It was concluded from their study that the coating shifted the boiling curve 
slightly to the left but with a smaller slope (lower wall superheat for the same heat flux). The coating achieved a maximum enhancement in heat transfer coefficient of $64 \%$. The current research group investigated local flow boiling of R245fa in a vertical cold drawn stainless steel tube of diameter $4.26 \mathrm{~mm}$, length $500 \mathrm{~mm}$ and coated with copper nanocoating, see Al-Gaheeshi et al. [73]. The coating was performed by Oxford Nanosystems Ltd. Figure 8 depicts the SEM images for the coated $(\mathrm{Ra}=0.675 \mu \mathrm{m})$ and the uncoated tubes $(\mathrm{Ra}=0.197 \mu \mathrm{m})$. The figure indicated that the surface of the uncoated tube is smoother with the existence of random pits, which could be nucleation sites. On the contrary, the SEM picture of the coated tube demonstrated that the surface is highly rougher than the uncoated tube and the microstructure of the coating is uniformly distributed over the surface. The structure and the uniform distribution of the coating are expected to increase the number of nucleation sites and thus the heat transfer rates. The heat transfer results are presented in Fig. 9 [73], which demonstrates that the trend of the heat transfer coefficient for the two tubes is nearly the same. Additionally, they reported that the amount of enhancement increased as the heat flux increased due to the activation of more nucleation sites in the coated surface. Figure $9 \mathrm{~b}$ showed that the average heat transfer coefficient increased linearly with heat flux with insignificant mass flux effect for both tubes. The average heat transfer coefficient is about $33 \%$ higher in the coated tube.

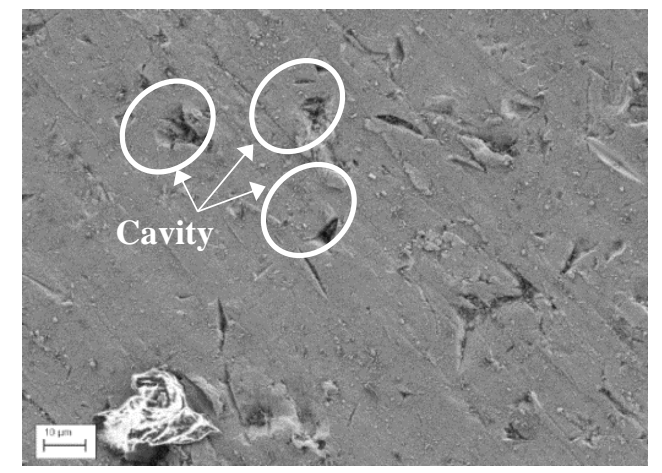

(a) Uncoated tube

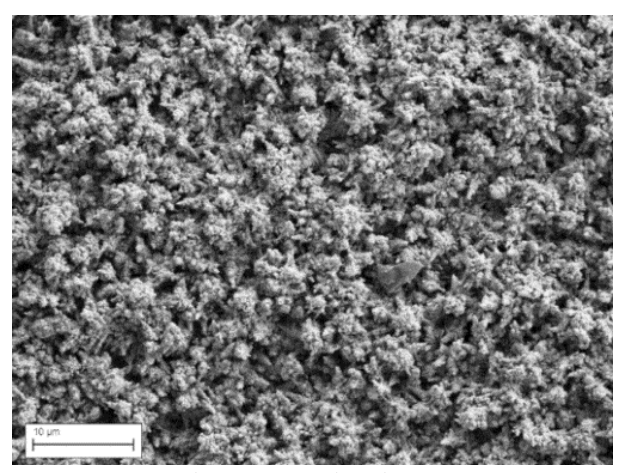

(b) Coated tube

Fig.8. TheSEM pictures for the uncoated and coated tube, Al-Gaheeshi et al. [73].

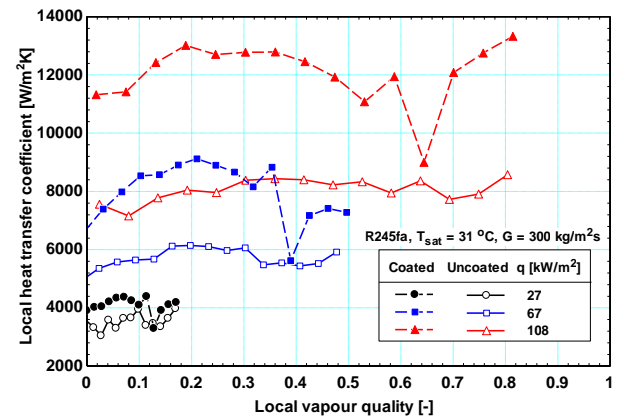

(a)

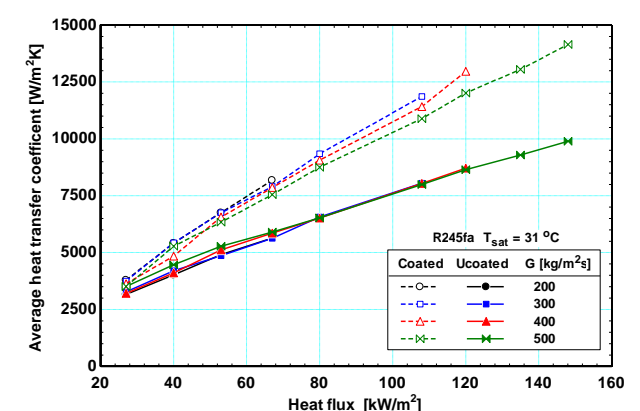

(b)

Fig. 9. (a) Effect of coating on the local heat transfer coefficient at $T_{\text {sat }}=31^{\circ} \mathrm{C}$ and $\mathrm{G}=300 \mathrm{~kg} / \mathrm{m}^{2} \mathrm{~s}$ and (b) effect of coating on the average heat transfer coefficient for different mass fluxes, [73].

6.3 Effect of Boiling Surface Material The material of the boiling surface could affect the surface finish and consequently the local heat transfer characteristics. Some researchers tested different materials and reported differences in the surface finish and heat transfer rates [74-77]. Additionally, the thermal properties of the boiling surface could affect the bubble growth rate and thus the bubble ebullition cycle. Mahmoud and Karayiannis [4] presented a thorough discussion to the effect of boiling surface material on bubble growth and heat transfer rates. They used a bubble growth model (Eq. (2) below) proposed by Cooper [77] to quantify the effect of the thermal properties of the wall on bubble growth. They conducted the evaluation using R134a and three materials (stainless steel, aluminum and copper) and the results are shown in Fig. 10. It was concluded that bubble growth rate on a copper surface is significantly higher than that occurring on aluminum and stainless steel surfaces. Additionally, bubble departure size is expected to be much larger with copper surfaces. The high bubble growth rate may enhance the overall heat transfer rates in the low heat flux region but heat transfer deterioration may occur at high heat fluxes due to the increased rate of bubble coalescence and the formation of dry patches on the surface. Finally, they concluded that the surface material should be taken into consideration at the design stage of boiling heat transfer surfaces. 


$$
r_{b}=1.12 J a \sqrt{\alpha_{l} t} \sqrt{\frac{k_{w} \rho_{w} c_{w}}{k_{f} \rho_{f} c_{p l}}}
$$

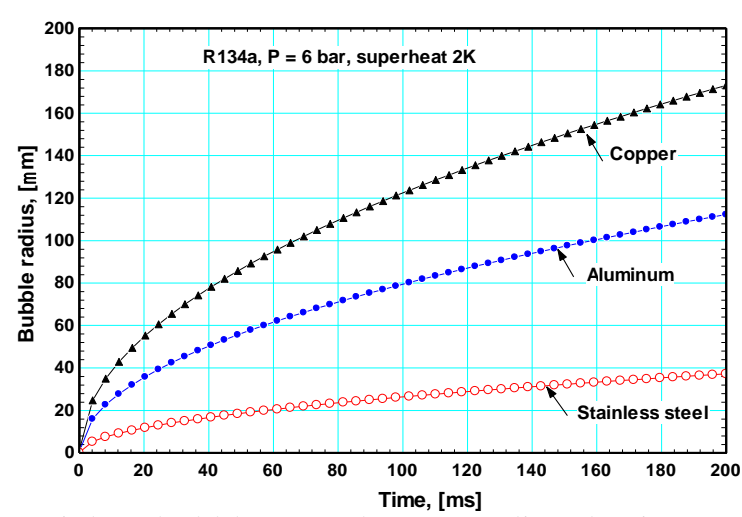

Fig. 10. Effect of material on bubble growth rate predicted using Eq. (2) by Cooper [77].

The effect of substrate material in flow boiling cannot be concluded from the literature due to the difference in operating conditions (mass flux, heat flux, and inlet conditions), type of fluid, diameter and heated length. To avoid the variations in the above parameters, the current research group tested flow boiling in cold drawn copper, brass and stainless steel tubes with $1.1 \mathrm{~mm}$ diameter and $300 \mathrm{~mm}$ length using R245fa, see PikeWilson and Karayiannis [78]. They conducted the tests in the mass flux range $100-400 \mathrm{~kg} / \mathrm{m}^{2} \mathrm{~s}$, heat flux range $10-60 \mathrm{~kW} / \mathrm{m}^{2}$, vapour quality up to 0.95 and 1.8 bar inlet pressure. The SEM image for the three investigated tubes are shown in Fig. 11 which indicates that the surface of the stainless steel tube exhibited some deposits, the brass surface showed imperfections and the copper surface is smooth with few longitudinal scratches. They also measured the average roughness and the values were $0.524 \mu \mathrm{m}$ for copper, $0.716 \mu \mathrm{m}$ for stainless steel and $1.249 \mu \mathrm{m}$ for brass. It was found that the heat transfer coefficient in the stainless steel tube exhibited local peaks with a tendency for increasing with vapour quality towards the exit. For the brass tube, there were no local peaks and the heat transfer coefficient remained nearly unchanged for vapour quality below 0.1 after which the heat transfer coefficient increased rapidly with vapour quality. For the copper tube, the heat transfer coefficient exhibited small fluctuations with vapour quality with increased trend towards the exit for some heat flux values. The local peaks found in the stainless steel tube were attributed to the surface flaws. Additionally, it was concluded that the method of analyzing the surface and processing the data could result in significant differences in the surface data. In this study, the researchers could not isolate the effect of the material, since the tube had different surface roughness and hence this requires further investigation.

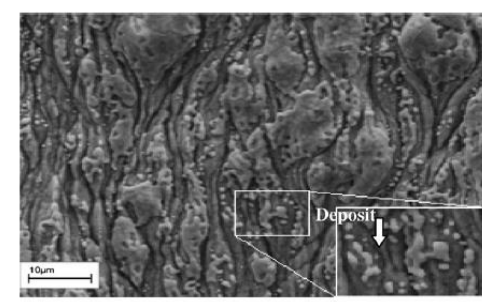

(a)

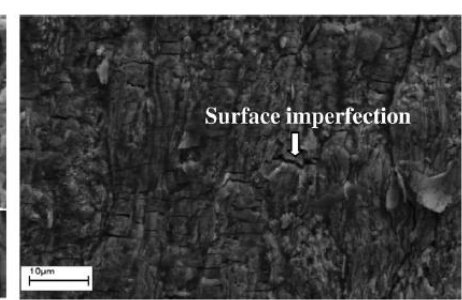

(b)

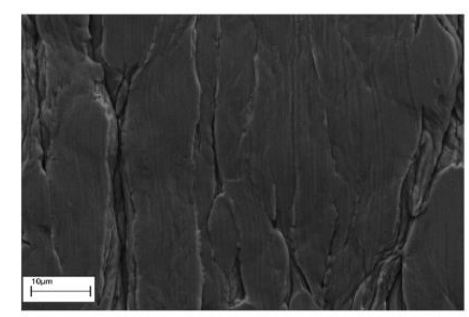

(c)

Fig. 11. SEM results for (a) stainless steel, (b) brass and (c) copper, Pike-Wilson and Karayiannis [78]. 


\section{EFFECT OF HEATED LENGTH}

This section presents and discusses the effect of heated length on local flow boiling heat transfer characteristics in single tubes. The literature on this is limited. Some researchers [79-81] studied flow boiling of R134a in stainless steel tubes having an inner diameter of $0.5 \mathrm{~mm}$ and different heated length, $550 \mathrm{~mm}$ in [79], $75 \mathrm{~mm}$ in [80] and $100 \mathrm{~mm}$ in [81]. They have reported completely different trends for the local heat transfer coefficient versus local vapour quality, which may be attributed to the difference in the heated length. However, inspecting their studies one can see that other factors could result in these differences in the trend of the local heat transfer coefficient versus local quality, see [4] for further information. Accordingly, it can be concluded that it is very difficult to understand the effect of heated length from the literature. This is because it is very difficult to find a number of experimental studies that cover exactly similar experimental conditions but different heated length. The current research group studied the effect of heated length on local saturated flow boiling of R134a in a tube with an inner diameter of $1.1 \mathrm{~mm}$ and heated length $150,300,450 \mathrm{~mm}$, see Karayiannis et al. [82]. They concluded that three flow regimes dominate for all tubes, namely slug, churn and annular flow. Annular flow appeared early at lower vapour quality for the longer tube $(x=0.44$ for $\mathrm{L}=150$ $\mathrm{mm}$ and $\mathrm{x}=0.25$ for $\mathrm{L}=450 \mathrm{~mm}$ ). The slug and churn flow regimes seem not to be influenced significantly when increasing the heated length, if the comparison was conducted at the same exit quality. The authors noted that if the comparison is done at the same heat flux, the flow patterns observed at the exit will be different (In this case the exit quality of the longest tube is much greater than the exit quality of the shortest). They concluded that further work is needed to clarify the effect of heated length on the flow patterns. A full discussion is available in ref. [82].

\section{EFFECT OF FLUID PROPERTIES}

Chen [83] investigated flow boiling patterns of R134a in vertical stainless steel tubes $(\mathrm{D}=1.1-4.26 \mathrm{~mm})$ at $T_{\text {sat }}=21.6-52.4^{\circ} \mathrm{C}$ (different fluid properties). It was found that as the saturation temperature increases, the transition from slug to churn and from churn to annular flow occurs at lower gas superficial velocities while the transition from bubbly to dispersed bubble occurred at lower liquid superficial velocities. Huo et al. [84] used stainless steel tubes with $\mathrm{D}=2.01$ and $4.26 \mathrm{~mm}$ and studied the effect of saturation temperature on the local heat transfer coefficient plotted versus local vapour quality $(x)$. It was found that the local heat transfer coefficient increased with increasing saturation temperature for all vapour qualities before dryout. Ong and Thome [40, 85] studied flow patterns and heat transfer of R134a, R236fa and R245fa in horizontal stainless steel tubes of 1.03, 2.20 and $3.04 \mathrm{~mm}$ inner diameter at $T_{\text {sat }}=25-35^{\circ} \mathrm{C}$. It was found that the transition from isolated bubble (bubbly and plug/slug) to coalescence bubble (plug/slug, churn and slug-annular) and from coalescence bubble to annular flow occurs at lower vapour quality for R245fa, followed by R236fa and R134a. The type of fluid was found to have a significant effect on the trend of the local heat transfer coefficient versus local vapour quality. For R134a, the heat transfer coefficient increased with increasing heat flux with little dependence on vapour quality for all vapour qualities. For R236fa and R245fa, the heat transfer coefficient increased with heat flux and decreased with vapour quality to a plateau in the isolated bubble and coalescence bubble regimes $(x \approx 0.15-0.25)$. In the annular flow regime $(x>0.15-0.25)$, all curves merged into one curve (no heat flux effect) with increasing trend with vapour quality. Charnay et al. [86, 87] investigated flow boiling of R245fa in a horizontal stainless steel tube $(\mathrm{D}=3 \mathrm{~mm})$ at very high saturation temperatures $60{ }^{\circ} \mathrm{C}-120^{\circ} \mathrm{C}$. The saturation temperature and mass flux was found to have a significant effect on the trend of the local heat transfer coefficient versus local vapour quality. For low mass flux $\left(\mathrm{G}=300 \mathrm{~kg} / \mathrm{m}^{2} \mathrm{~s}\right)$ and $T_{\text {sat }}=60-100{ }^{\circ} \mathrm{C}$, the local heat transfer coefficient was independent of vapour quality for all vapour qualities (up to $\approx 0.85$ ) while for $T_{\text {sat }}=120^{\circ} \mathrm{C}$, the heat transfer coefficient decreased continuously with vapour quality. For high mass flux $\left(\mathrm{G}=700 \mathrm{~kg} / \mathrm{m}^{2} \mathrm{~s}\right)$ and $T_{\text {sat }}=60-80{ }^{\circ} \mathrm{C}$, the heat transfer coefficient indicated insignificant variations with vapour quality in the low quality region $\mathrm{x}<0.2$ (bubbly, bubbly-slug, slug) while the coefficient increased significantly with vapour quality in the high quality region (annular flow). For $T_{\text {sat }}=100-120{ }^{\circ} \mathrm{C}$, the heat transfer coefficient decreased with vapour quality in the low quality region $\mathrm{x}<0.2$ (bubbly, bubbly-slug, slug) then remained almost unchanged in the annular flow regime until the occurrence of dryout.

Al-Gaheeshi et al. [73] studied flow boiling of R134a and R245fa in a vertical stainless steel tube having an inner diameter $4.26 \mathrm{~mm}$ and $500 \mathrm{~mm}$ heated length. Their flow visualization study indicated that the flow patterns of the two fluids are different, see Fig. 13. For R134a, bubbly, slug, churn and annular flow were 
observed while no bubbly flow was observed for R245fa. In addition, the slug, churn and annular flow of R245fa occurred at lower vapour qualities compared to R134a. They attributed the differences in flow patterns and heat transfer rates to the difference in fluid properties; variations in liquid viscosity, gas density and surface tension, which affect the bubble ebullition cycle as previously discussed in section 5. For more information and discussion, the interested reader is referred to refs. $[4,73]$. The appearance of bubbly flow with R134a and its disappearance with R245fa was attributed to the effect of fluid properties on nucleation characteristics such as the minimum wall superheat and bubble departure diameter and frequency. Al-Gaheeshi et al. [73] reported also on the local heat transfer coefficient versus vapour quality for the two fluids as seen in Fig. 16, which demonstrates that, for R134a, the heat transfer coefficient exhibited strong dependence on heat flux with small variations with vapour quality up to $\mathrm{x} \approx 0.5$, after which the heat transfer coefficient decreased rapidly indicating the occurrence of local dryout. For R245fa, the heat transfer coefficient revealed weak dependence on heat flux compared to R134a and insignificant dependence on vapour quality without local dryout. When they compared the two fluids using the average heat transfer coefficient, it was found that the average heat transfer coefficient increases with increasing heat flux with insignificant mass flux effect for both fluids. The magnitude of the average heat transfer coefficient of R134a is significantly higher than that of R245fa (about $151 \%$ and $106 \%$ respectively) for saturation temperature $31^{\circ} \mathrm{C}$ and $39^{\circ} \mathrm{C}$. The enhancement may be due to the higher gas to liquid density ratio of R134a compared to that of R245fa which results in a lower void fraction for the same saturation temperature. Hence the liquid film in slug and annular flow is thicker for R134a than R245fa and provides the possibility of activating more nucleation sites in the liquid film. The enhancement in heat transfer due to nucleation in the thick liquid film seems to be greater than the reduction in the heat transfer rate due to the increased thermal resistance of the liquid film. However, this needs further clarification.

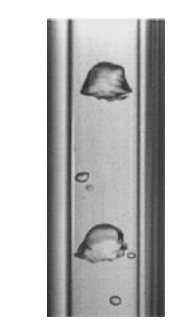

$\mathrm{x}=0.002$

bubbly

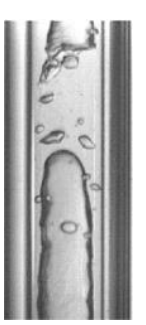

0.101

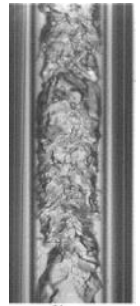

0.284

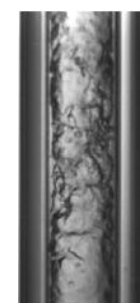

0.393

(a)

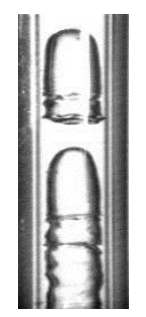

$\mathrm{x}=0.001$

slug

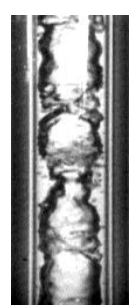

0.101

churn

(b)

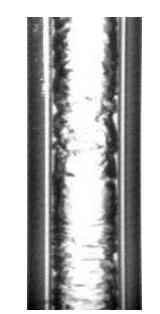

0.315

annular

Fig.13. Flow patterns of R134a (a) and R245fa (b) at $\mathrm{G}=200 \mathrm{~kg} / \mathrm{m}^{2} \mathrm{~s}$ and $T_{\text {sat }}=39^{\circ} \mathrm{C}$, Al-Gaheeshi et al. [73].

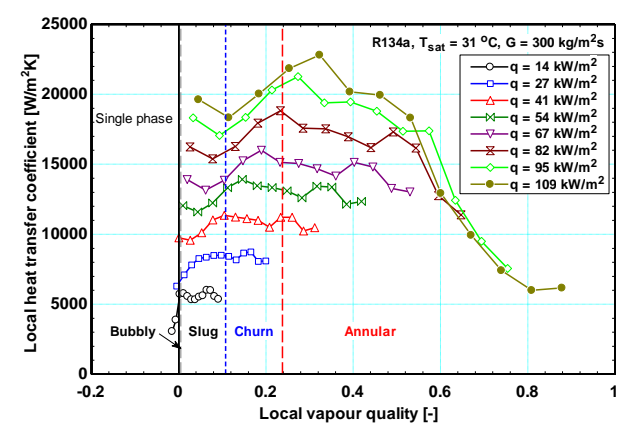

(a)

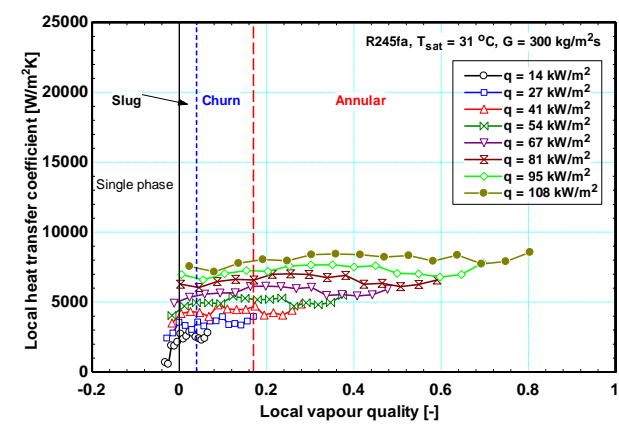

(b)

Fig. 14. Effect of heat flux and vapour quality on the local heat transfer coefficient at $G=300 \mathrm{~kg} / \mathrm{m}^{2} \mathrm{~s}$ and $\mathrm{T}_{\text {sat }}$ $=31^{\circ} \mathrm{Cfor}$ (a) R134a, (b) R245fa, Al-Gaheeshi et al. [73].

\section{FLOW INSTABILITY AND REVERSAL}

Flow boiling instability is one of the critical issues that may hinder the commercial applications of two phase flow in microchannels heat sinks. This arises from the fact that it might cause a significant reduction in the overall system performance. The fluctuations due to instability can be as high as $36 \mathrm{~K}$ for wall temperature, as found by Wang et al. [88], and $992.4 \mathrm{~kg} / \mathrm{m}^{2} \mathrm{~s}$ and $60 \mathrm{kPa}$ for mass flux and pressure drop, respectively, as found by Fu et al. [89]. Thus, this issue should be taken into consideration at the early stages of design of two phase microchannels heat exchangers. Karayiannis and Mahmoud [1] discussed and summarized the possible reasons for flow instability as follows: (1) Rapid bubble growth and expansion in the upstream and downstream sides 
of the channel, [90 - 94]. (2) The size of the outlet plenum - single channel, Qi et al [91]. (3) Inlet compressibility effects $[95,96]$, i.e. the presence of a compressible volume ahead of the test section. (4) Nucleation near the channel inlet, Kandlikar [97]. The interested reader is referred to ref. [1] for more details. Fayyadh et al. [98] investigated flow boiling of R134a in a copper, multi-microchannel evaporator $(0.3 \times 0.7$ $\mathrm{mm}$ ) in the mass flux range $50-300 \mathrm{~kg} / \mathrm{m}^{2} \mathrm{~s}$. They reported that flow reversal depends on mass flux. For $\mathrm{G}=$ $50 \mathrm{~kg} / \mathrm{m}^{2} \mathrm{~s}$, flow reversal was observed at boiling incipience and continued for all heat fluxes. An example on flow reversal at $G=50 \mathrm{~kg} / \mathrm{m}^{2} \mathrm{~s}$ is depicted in Fig. 15, which shows the sequence of pictures. This figure indicated that the vapour patch stays for about $210 \mathrm{~ms}$ in the inlet manifold, with back and forth motion, before its rupture into segmented bubbles that moved downstream. As the mass flux increased, the heat flux at which flow reversal occurred increased. Very mild flow reversal was observed in the inlet manifold at a base heat flux of $149 \mathrm{~kW} / \mathrm{m}^{2}$ for $\mathrm{G}=300 \mathrm{~kg} / \mathrm{m}^{2} \mathrm{~s}$, where the vapour patch stayed only for about $10 \mathrm{~ms}$ in the inlet manifold.

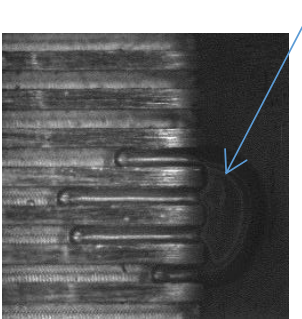

$0 \mathrm{~ms}$

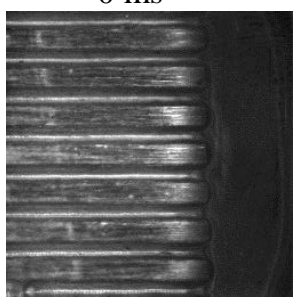

$24 \mathrm{~ms}$

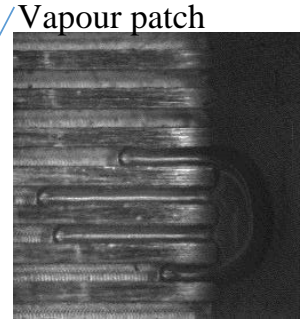

$6 \mathrm{~ms}$

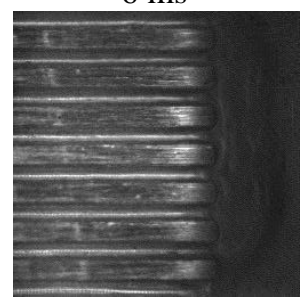

$113 \mathrm{~ms}$

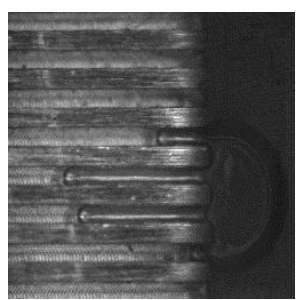

$13 \mathrm{~ms}$

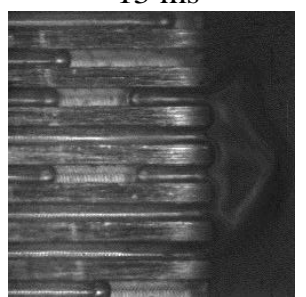

$154 \mathrm{~ms}$

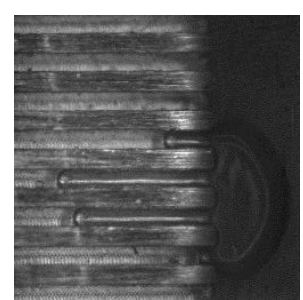

$16 \mathrm{~ms}$

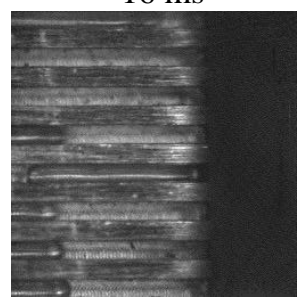

$187 \mathrm{~ms}$

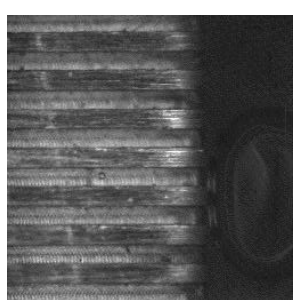

$23 \mathrm{~ms}$

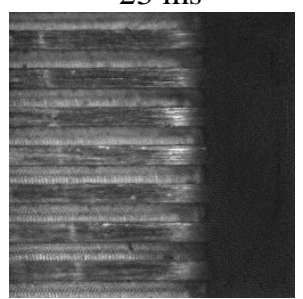

$210 \mathrm{~ms}$

Fig. 15. Sequence of pictures for flow reversal observed at $\mathrm{G}=50 \mathrm{~kg} / \mathrm{m}^{2} \mathrm{~s}, \mathrm{P}=6.5$ bar and R134a, Fayyadh et al. [98].

In current research Al-Zaidi [99], the growth of a bubble further downstream but still near the channel inlet and at its centerline was observed using a high-speed, high-resolution camera. The experiments were performed with HFE-7100 in a multichannel test section consisting of 25 channels of dimensions $0.35 \mathrm{~mm}$ in height and $0.7 \mathrm{~mm}$ width and a mass flux of $50 \mathrm{~kg} / \mathrm{m}^{2} \mathrm{~s}$ and a heat flux of $51.1 \mathrm{~kW} / \mathrm{m}^{2}$. As seen in the sequence of photograph of Fig. 16, the bubble grows from the channel corner and after coalescing with smaller bubbles grows explosively in both directions possibly causing flow reversal.

To reduce flow reversal, some researchers $[100,101]$ proposed inserting a flow restrictor at the channel inlet or using channels with diverging cross section [102]. Kosar et al [100] used a rectangular orifice with a fixed width of $20 \mu \mathrm{m}$ and a variable length at each channel inlet to stabilize the flow. It is interesting to note that, although the flow was deemed stable, the surface temperature reached a value of about $180{ }^{\circ} \mathrm{C}$ at $\mathrm{G}=389$ $\mathrm{kg} / \mathrm{m}^{2} \mathrm{~s}$. This value is very high if this heat sink is to be used for electronics cooling. It is not clear whether this high surface temperature is linked to the inlet restrictor or not. Kuan and Kandlikar [101] reported that the heat transfer rate and flow stability were improved for channels with inlet restrictions compared to channels without restrictors. In their testing module, each channel was connected to the inlet manifold through a $0.127 \mathrm{~mm}$ diameter hole which represented $6.1 \%$ of the channel cross section area. However, inspecting their results, one can see that the inlet restrictor reduced the surface temperature by about $1 \mathrm{~K}$ for the same heat flux. In other words, the enhancement in the heat transfer coefficient was about $11 \%$, which was comparable to the experimental uncertainty. Additional reasons for flow reversal were reported by Karayiannis and Mahmoud [1] which include the size of the inlet/outlet manifold and using channels with sufficient number of nucleation sites. They also recommended further studies on this issue assessing the use of surfactants, the effect of wettability and the channel material (thermal conductivity - conjugate effects) on flow instability and reversal. 


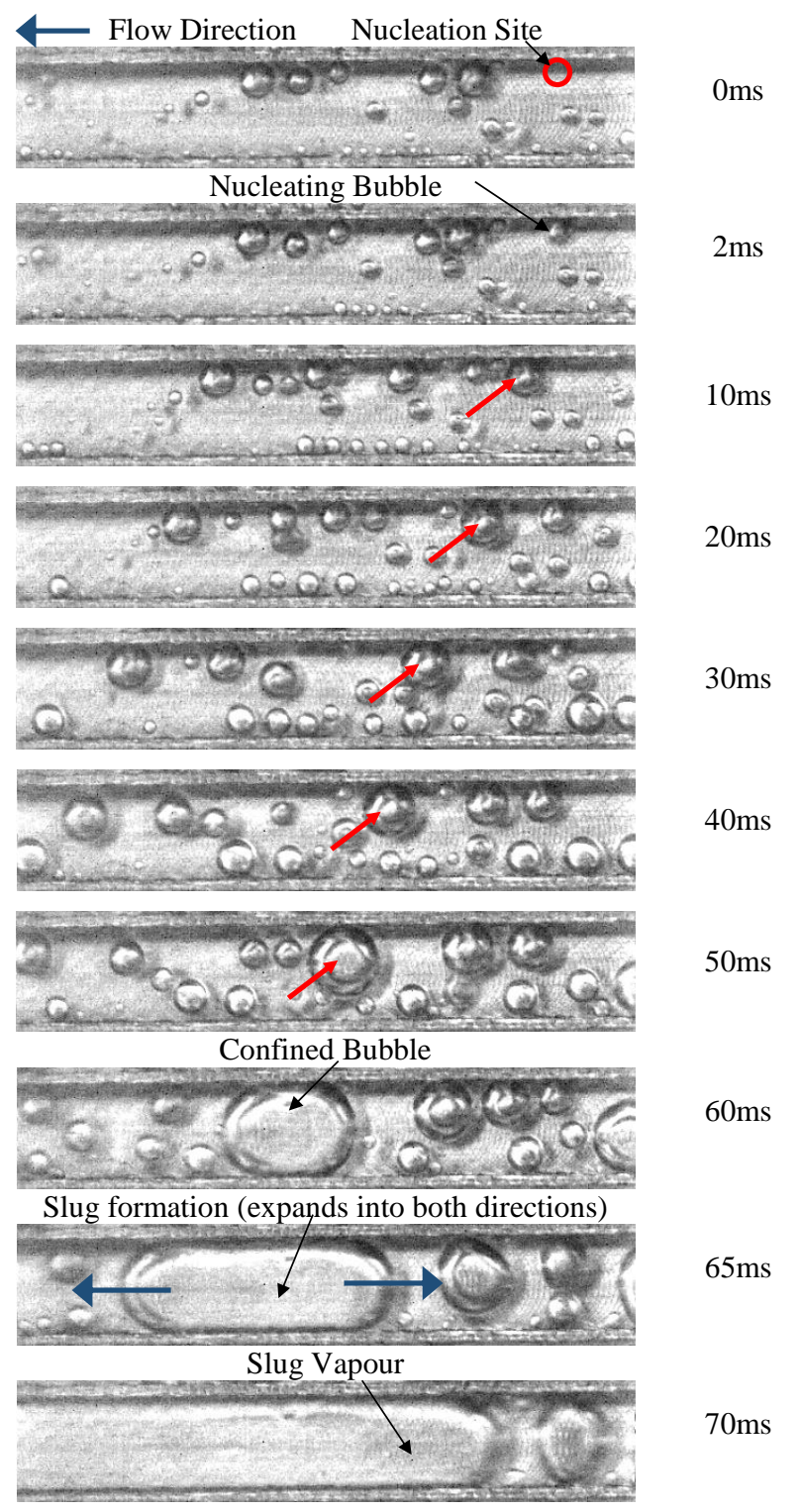

Fig. 16. Sequence of photographs showing bubble growth and expansion both upstream and downstream the channel for flow boiling of HFE-7100 in a multichannel test section of channel dimensions $0.35 \mathrm{~mm}$ in height and $0.7 \mathrm{~mm}$ width and a mass flux of $50 \mathrm{~kg} / \mathrm{m}^{2} \mathrm{~s}$ and a heat flux of $51.1 \mathrm{~kW} / \mathrm{m}^{2}$, [99].

\section{EFFECT OF CHANNEL ASPECT RATIO}

In rectangular microchannels the flow patterns, heat transfer mechanisms and rates and pressure drop can be affected by the aspect ratio of the channels, defined here as $A R=$ channel width/channel height. Singh et al. [103] studied flow boiling of water in rectangular silicon microchannels of hydraulic diameter $0.142 \mathrm{~mm}, 20$ $\mathrm{mm}$ long and aspect ratios ranging from 1.23 to 3.75 . They reported that the channel with $A R=1.56$ provided the smallest pressure drop. Soupremanien et al. [104] used Forane 365HX in two stainless steel channels of hydraulic diameter $1.4 \mathrm{~mm}$ and $A R=2.3$ and 7 . They reported that at low heat flux, the heat transfer coefficient was higher for the channel of $A R=7$ but the trend reversed at high heat flux, i.e. the heat transfer coefficient was lower at this aspect ratio. The pressure drop was lower for the high aspect ratio channel. Fu et al. [105] carried out flow boiling experiments with HFE-7100 in a diverging copper channel of hydraulic diameter approximately 1.2 and aspect ratio ranging between from 0.83 to 6.06 . They noted a significant aspect ratio effect with a maximum heat transfer coefficient at $A R=0.99$. Markal et al. [106] studied the effect of aspect ratio in six silicon heat sinks $48 \mathrm{~mm}$ long and $13.5 \mathrm{~mm}$ wide consisting of 29 rectangular channels. These had the same hydraulic diameter of $0.1 \mathrm{~mm}$ and aspect ratio ranging from 0.37 to 5.0. They used water as the working fluid. They concluded that the heat transfer coefficient increases with increasing aspect ratio up to 
$A R=3.54$ and then decreases. Özdemir et al. [107] studied flow boiling of water in single copper channels of hydraulic diameter $0.56 \mathrm{~mm}$, length $62 \mathrm{~mm}$ and $\mathrm{AR}=0.5,2.56$ and 4.99 . The authors reported that the heat transfer coefficient increased as the aspect ratio decreased up to a heat flux of approximately $500 \mathrm{~kW} / \mathrm{m}^{2}$. For higher heat flux values the aspect ratio had no effect. Al-Zaidi et al. [108] carried out experiments with HFE7100 in three different heat sinks $20 \mathrm{~mm}$ wide and $25 \mathrm{~mm}$ long having rectangular channels. The hydraulic diameter of the channels was $0.46 \mathrm{~mm}$ and the $A R=0.5,1.0$ and 2.0. Results from this work are depicted in figure 17 as heat transfer coefficient versus vapour quality. As seen in the figure, the local (and average) heat transfer coefficient increases with aspect ratio.

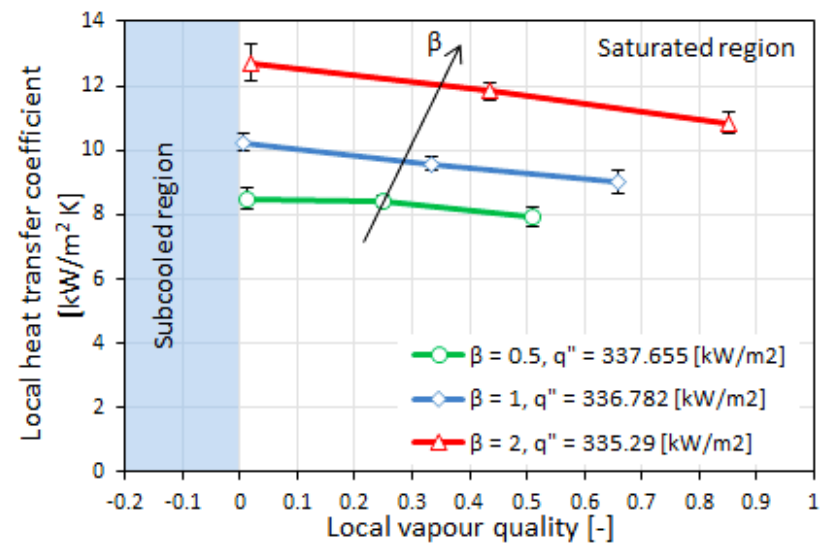

Fig. 17. Channel aspect ratio effect at mass flux of $250 \mathrm{~kg} / \mathrm{m}^{2} \mathrm{~s}$ and different base heat fluxes, [108].

As a summary in this section, it is noted that the effect of aspect ratio on flow patterns, heat transfer mechanisms and rates and pressure drop needs to be investigated further. The aspect ratio effect may then need to be included in correlations predicting flow patterns, heat transfer rates and pressure drop. These studies should be done for a range of heat flux, mass flux and system pressure and possibly different fluids with channels of the same hydraulic diameter and surface roughness to allow clear and conclusive results on the actual effect of the aspect ratio.

\section{DOMINANT HEAT TRANSFER MECHANISMS}

It is well known that the dominant flow boiling heat transfer mechanisms in large diameter channels are nucleate and convective boiling. Nucleate boiling dominates up to intermediate vapour qualities where the flow pattern is bubbly, slug and churn. In this mechanism, the heat transfer coefficient depends on heat flux and system pressure but independent of mass flux and vapour quality. On the other hand, convective boiling dominates at high vapour quality when the flow pattern becomes annular and the nucleation process is nearly suppressed. In this mechanism, the heat transfer coefficient depends on vapour quality and mass flux but independent of heat flux. These criteria have also been applied to flow boiling in microchannels with various conclusions were reached by different research groups; nucleate boiling $[109,110]$, nucleate and convective boiling [111 - 113], convective boiling [114 - 116] and thin film evaporation [117-120]. Only one study by Yen et al. [121] reported the suppression of both nucleate and convective boiling mechanisms and attributed the deterioration in heat transfer coefficient in their study to this suppression. Another study by Basu et al. [122] reported that the boiling mechanism was not clear. Harirchian and Garimella $[123,124]$ conducted an experimental study on flow boiling of FC-77 in silicon multi-microchannels with a fixed depth of $400 \mu \mathrm{m}$ and widths ranging from 100 to $5850 \mu \mathrm{m}$ with a mass flux range of $225-1600 \mathrm{~kg} / \mathrm{m}^{2} \mathrm{~s}$. Based on heat and mass flux effects, nucleate boiling was found to be the dominant heat transfer mechanism in all cases, except, for channels with width of 100 and $250 \mu \mathrm{m}$ and mass flux of $250 \mathrm{~kg} / \mathrm{m}^{2} \mathrm{~s}$. Accordingly, they concluded that convective boiling is more important as the channel size and mass flux decrease. In other words, channel size affects the heat transfer mechanism. Their flow visualization demonstrated that small nucleating bubbles were observed in the liquid slugs between the consecutive bubbles and also in the liquid film of wispy-annular flows. Even in annular flow, bubble nucleation in the film was observed, but it disappeared after a certain heat flux. Borhani and Thome [125] investigated the intermittent dewetting and dryout in annular flow using R245fa and a silicon multi-microchannel evaporator. They also observed small nucleating bubbles in the annular liquid film at a mass flux of $150 \mathrm{~kg} / \mathrm{m}^{2} \mathrm{~s}$ and $140 \mathrm{~kW} / \mathrm{m}^{2}$. The possibility of having small nucleating bubbles in the liquid film region in slug and annular flows encourages the question on the contribution of the nucleation 
compared to thin film evaporation. Contrary to the above studies, Ali et al. [119] investigated flow boiling of $\mathrm{R} 134 \mathrm{a}$ and $\mathrm{R} 245 \mathrm{fa}$ in a directly heated quartz tube with a diameter $0.781 \mathrm{~mm}$. They did not observe nucleating bubbles in the liquid film around the elongated bubble. Thus, they concluded that nucleation was suppressed and thin film evaporation is the dominant mechanism in the elongated bubble regime. It is worth noting that, based on the effect of mass and heat flux on the heat transfer coefficient, nucleate boiling is the dominant heat transfer mechanism in their study. However, based on flow visualization, they reported that nucleation was restricted to a region close to the tube inlet (very low vapour quality or bubbly flow) while no nucleation was observed along the rest of the tube.

Bigham and Moghaddam [126] designed a well-instrumented test section to investigate the local heat transfer mechanisms in a single microchannel $(0.3 \mathrm{~mm}$ wide, $0.075 \mathrm{~mm}$ wall thickness and unspecified height) using FC-72. Their results showed that three mechanisms contribute to the heat transfer process in the elongated bubble regime, namely: (1) Micro-convection mechanism during the passage of the liquid slug. The heat flux and the heat transfer coefficient demonstrates single phase behaviour; (2) Thin film evaporation (microlayer evaporation); (3) Transient heat conduction, which occurs when the rear of the bubble passes over the sensor in the microchannel wall and rewets the dry patch underneath the bubble.

The above summary clearly verifies that there is still disagreement on the dominant heat transfer mechanism(s) and further work is needed, which should include a wide range of fluid properties (fluids), surface characteristics, channel geometry, mass flux, heat flux and pressure drop

\section{RECOMMENDATIONS FOR DESIGN}

11.1. Prediction of Flow Patterns Transitions The current authors proposed a prediction method for flow pattern transition boundaries, which was based on the work conducted by Chen [83]. The interested reader is referred to Karayiannis et al. [127] and Mahmoud and Karayiannis [128]. The new method was proposed after an extensive evaluation study to the existing models and correlations which indicated that there was a large discrepancy among all examined models. The prediction method is summarized in the Table (1) and the proposed map is shown in Fig. (16):

Table 1 Summary of the equations used for the prediction of flow pattern transition boundaries proposed by [128]

\begin{tabular}{|c|c|}
\hline Boundary & Equations \\
\hline Bubbly to slug & $U_{r}=\frac{u_{g s}}{\alpha_{c}}-\frac{u_{l s}}{1-\alpha_{c}}$ \\
\hline Slug to churn & $\begin{aligned} u_{g s} & =587.1\left(\frac{\mu_{l}}{\rho_{g} D}\right)^{1.447}\left(\frac{\rho_{g} D}{\sigma}\right)^{0.937} \\
F r_{g s}^{*} & =u_{g s} \sqrt{\rho_{g} / \Delta \rho g D}\end{aligned}$ \\
\hline Churn to annular & $W e_{l s}=1.567 \times 10^{-17}\left(F r_{g s} \operatorname{Re}_{g s}\right)^{3.41}$ \\
\hline
\end{tabular}

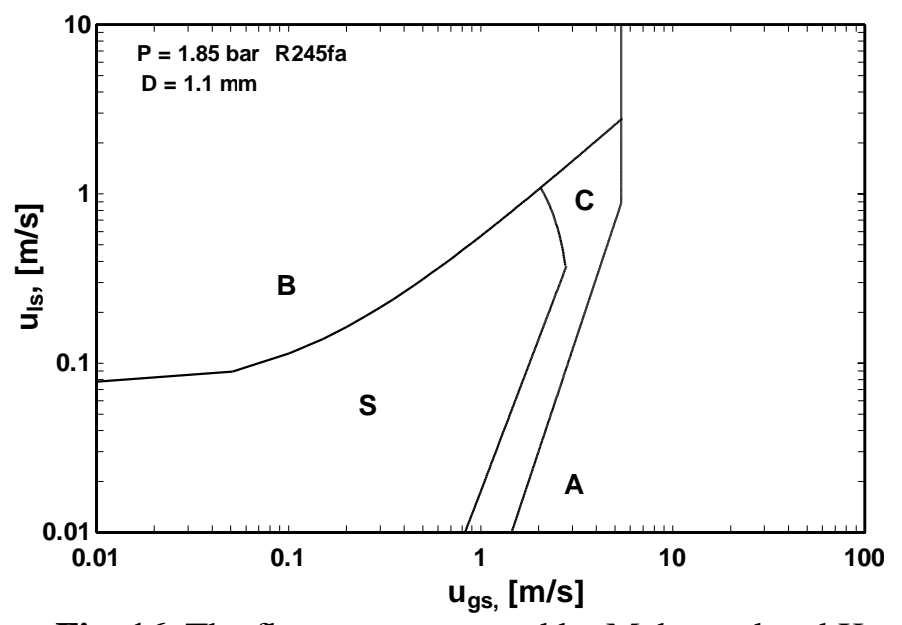

B: bubbly,

S: slug,

C: churn,

A: annular

Fig. 16. The flow map proposed by Mahmoud and Karayiannis [128]. 
11.2. Prediction of the Heat Transfer Coefficient Mahmoud and Karayiannis [129] evaluated 21 macro and micro scale correlations for the prediction of flow boiling heat transfer coefficient using experimental data for R-134a, [129]. The reader is referred to their paper for the summary and details of these models and correlations. The result of their evaluation study indicated that all examined models and correlations could not predict the experimental data well. Thus, they proposed two different correlations, see [129 - 131] for more details. The first correlation was based on fitting the experimental data as a function of dimensionless numbers, as given by Eq. (3) below. This correlation predicted $90.5 \%$ of their data within the $\pm 30 \%$ error bands and 15 $\%$ mean absolute error. Anwar et al. [132, 133] evaluated this correlation using data for R134a, R152a and R600a and reported that it could predict $99.14 \%$ of the R152a data, $96.11 \%$ of the R134a data and $89.9 \%$ of the R600a data to within $\pm 30 \%$.

$$
\alpha_{t p}= \begin{cases}3320 \frac{B o^{0.63} W e^{0.2} \mathrm{Re}_{f}^{0.11}}{C o^{0.6}} \frac{k_{f}}{D} & \text { for } D=4.26,2.88,2.01,1.1 \text { before dryout and } 0.52 \mathrm{~m} m \text { for } x<0.3 \\ 5324\left[\frac{B o^{0.3} W e^{0.25}}{N_{C o}^{0.25}}\right]^{1.79} \frac{k_{f}}{D} & \text { for } D=0.52 m m \text { and } x>0.3\end{cases}
$$

The second correlation was based on the model of Chen [135], which combined the contribution of nucleate and convective boiling mechanisms, as given by Eqs. (4 - 9). It predicted $92 \%$ of the data of Mahmoud and Karayiannis [130] with a mean absolute error $14.3 \%$. Fayyadh et al. [99] assessed this correlation using data for flow boiling of R134a in a multi-microchannel evaporator. The correlation predicted their data at a mean absolute error of $19 \%$.

$$
\begin{gathered}
\alpha_{t p}=S_{\text {new }} \alpha_{\text {Cooper }}+F_{\text {new }} \alpha_{f} \\
\alpha_{f}= \begin{cases}4.36 \frac{k_{f}}{D} & \operatorname{Re}_{f}<2000 \\
0.023 \operatorname{Re}_{f}^{0.8} \operatorname{Pr}_{f}^{0.4} \frac{k_{f}}{D} & \operatorname{Re}_{f}>3000\end{cases} \\
\operatorname{Re}_{f}=\frac{(1-x) G D}{\mu_{f}} \\
S_{\text {New }}=\left(1+\frac{A}{\mathrm{X}}\right)^{0.64} \\
A=2.812 C o^{-0.408} \\
1 \\
1+2.56 \times 10^{-6}\left(\operatorname{Re}_{f} F_{\text {New }}^{1.25}\right)^{1.17}
\end{gathered}
$$

\section{CONCLUSIONS AND RECOMMENDATIONS}

The current keynote paper discussed several fundamental aspects of flow boiling in mini to micro passages and presented new research published by the current research group. Some possible applications of microchannels heat sinks were briefly discussed at the beginning of the paper. The following conclusions can be drawn:

1. Flow boiling in microchannels is a very promising method for cooling high heat flux devices as part of an integrated pumped system and has the potential to offer energy recovery and savings in applications such as in the computer and IT industry.

2. The demarcation point between macro, small or mini and micro is very complex and still needs to be concluded. This requires detailed studies considering all relevant parameters.

3. The choice of working fluid and its response to the surface microstructure needs to be considered in all designs as the range of active cavity sizes decreases with increasing surface tension and/or decreasing $\rho_{g} h_{f g}$ term. At the same time, the required wall superheat at boiling incipience for different fluids proposed for use in microchannels should be considered. 
4. The bubble departure is driven by forces acting on the nucleating bubble. Therefore the bubble departure size is not affected significantly by fluid properties in flow boiling systems. The forces that are important in microchannels are the drag and surface tension forces.

5. The bubble generation frequency depends significantly on fluid properties. Therefore the flow patterns that can prevail in microchannels are more influenced by the bubble generation frequency rather than the bubble departure size.

6. There is no final agreement on the dominant heat transfer mechanism(s). Both nucleate and convective mechanisms can contribute significantly to the heat transfer process in microchannels; it is difficult to segregate the contribution of each mechanism.

7. The extent of flow instability and reversal depends on flow parameters and on channel surface characteristics, surface wettability, conjugate heat effects and the size of the inlet and outlet manifolds.

8. Channel surface characteristics have a significant effect on the behaviour of the local heat transfer coefficient. In addition, surface modification by micro or nano coating exhibited significant enhancement in heat transfer rates and critical heat flux. The reported enhancement can depend on the channel geometry.

9. The results presented with copper, stainless steel and brass tubes indicate that trend of the local heat transfer coefficient depends on the tube material.

10. The current results indicated that, the dependence of the heat transfer coefficient on heat flux and vapour quality can change with changes in the tube heated length.

11. In rectangular small and micro channels the aspect ratio can influence the flow boiling patterns, heat transfer mechanisms and rates and pressure drop.

12. Design correlations for the prediction of flow patterns and heat transfer in small to micro diameter channels are given in the paper.

The above discussion and conclusions are also indicative of further research and clarification needed in this area.

\section{NOMENCLATURE}

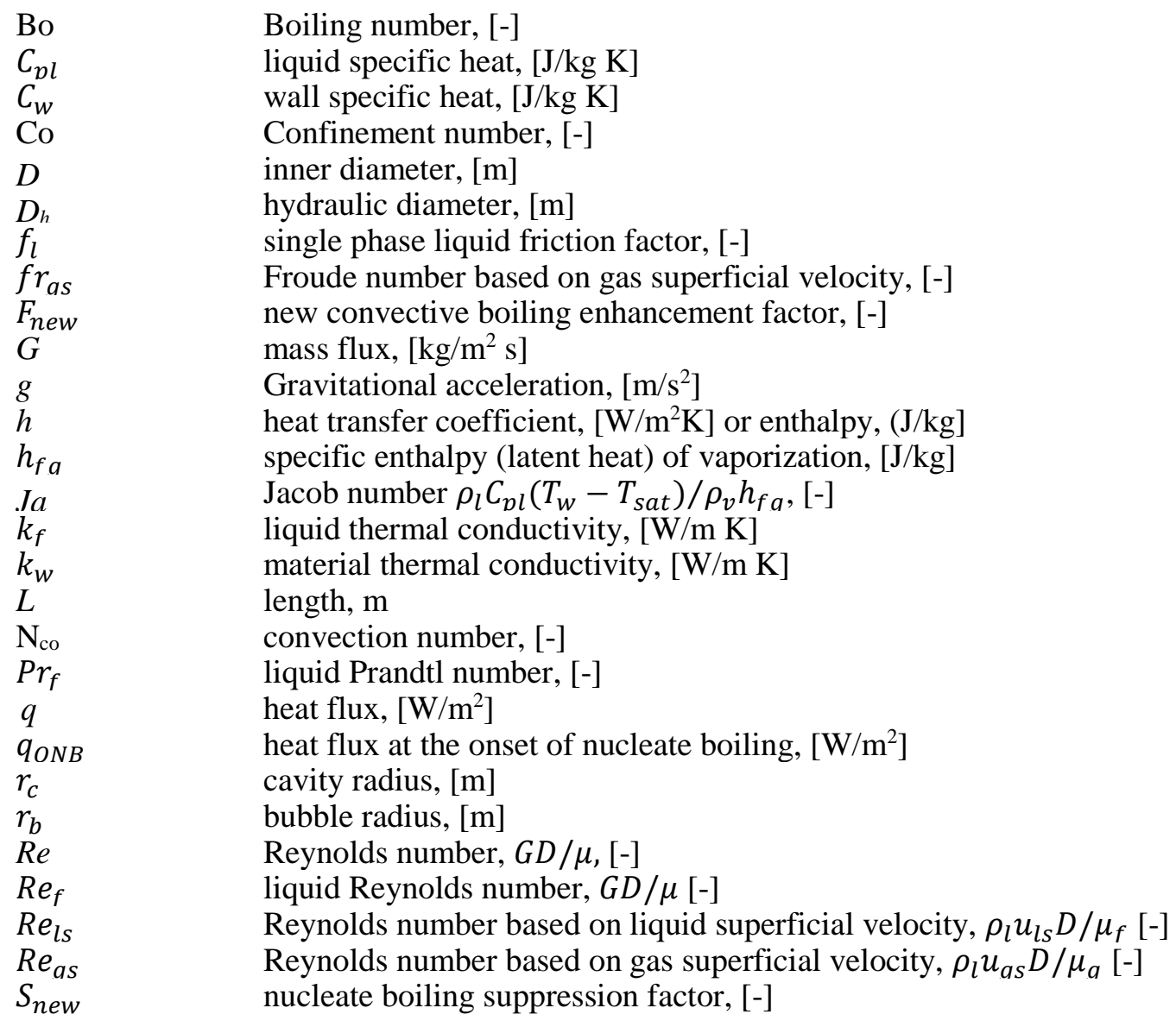




$\mathrm{t}$
$\Delta T_{s u p}$
$\Delta T_{s u b}$
$u_{l s}$
$u_{a s}$
$u_{h}$
$U_{r}$
$\mathrm{We}_{\mathrm{ls}}$
$\mathrm{We}$
$\mathrm{X}$
$x$

\section{Greek symbols}

$\alpha_{l}$
$\alpha_{c}$
$\alpha_{\text {cooper }}$
$\alpha_{t p}$
$\alpha_{f}$
$\delta_{t}$
$\mu_{f}$
$\mu_{a}$
$\rho_{a}$
$\rho_{l}$
$\rho_{w}$
$\sigma$

time, [s]

superheat degree, [K]

subcooling degree, $[\mathrm{K}]$

liquid superficial velocity, $[\mathrm{m} / \mathrm{s}]$

gas superficial velocity, $[\mathrm{m} / \mathrm{s}]$

homogeneous velocity, $[\mathrm{m} / \mathrm{s}]$

relative velocity, $[\mathrm{m} / \mathrm{s}]$

Weber number based on liquid superficial velocity, [-]

Weber number based on gas superficial velocity, [-]

Martinelli parameter, [-]

vapour quality, [-]

liquid thermal diffusivity, $\left[\mathrm{m}^{2} / \mathrm{s}\right]$

critical void fraction, [-]

Cooper pool boiling heat transfer coefficient, $\left[\mathrm{W} / \mathrm{m}^{2} \mathrm{~K}\right]$

two phase heat transfer coefficient, [W/ $\left.\mathrm{m}^{2} \mathrm{~K}\right]$

single phase heat transfer coefficient, [W/ $\left.\mathrm{m}^{2} \mathrm{~K}\right]$

thermal boundary layer thickness, [m]

liquid viscosity, [Pas]

gas viscosity, [Pas]

vapour density, $\left[\mathrm{kg} / \mathrm{m}^{3}\right]$

liquid density, $\left[\mathrm{kg} / \mathrm{m}^{3}\right]$

wall material density, $\left[\mathrm{kg} / \mathrm{m}^{3}\right]$

surface tension, $[\mathrm{N} / \mathrm{m}]$

\section{REFERENCES}

[1] Karayiannis, T. G. and Mahmoud, M. M., "Flow boiling in microchannels: Fundamentals and applications," Applied Thermal Engineering., 115, pp. 1372-1397, (2017)

[2] Recinella A., and Kandlikar, S. G., "Enhanced flow boiling using radial open microchannels with manifold and offset strip fins," J. of Heat Transfer, 140, pp. 021502 -1- 021502 - 9, (2018)

[3] Drummond K. P., D. Back, M. D. Sinanis, D. B. Janes, D. Peroulis, J. A. Weibel, S. V. Garimella, "A hierarchical manifold microchannel heat sink array for high heat flux two phase cooling of electronics," Int. J. Heat Mass Transfer, 117, pp. 319 - 330, (2018).

[4] Mahmoud, M. M. and Karayiannis, T. G., "Flow boiling in mini to micro diameter channels, Encyclopedia of Two Phase Heat Transfer and Flow IV, vol. 3, Chapter 4, (2018)

[5] Avgerinou, M., Paolo B., Luca C., "Trends in data center energy consumption under the European Code of Conduct for data center energy efficiency," Energies (2017), 10, 1470.

[6] Ni J., and Bai X., "A review of air conditioning energy performance in data centers,” Renew. Sustain. Energy Rev., 67, 625 640, (2017).

[7] Barbosa J. R., G. B. Ribeiro, P. A., De Oliveira, "A state-of-the-art-review of compact vapour compression refrigeration systems and their applications", Heat Transfer Engineering 33(4 - 5): 356 - 374, (2012)

[8] Mongia, R., Masahiro, K., Distefano, E., "Small Scale Refrigeration System for Electronics Cooling Within a Notebook Computer", The IEEE $10^{\text {th }}$ Intersociety Conf. on Thermal and Thermochemical Phenomena in Electronics Systems, (2006).

[9] Wu, Y.-T., Ma, C.-F., Zhong, X.-H., "Development and Experimental Investigation of a Miniature-Scale Refrigeration System", Energy Conversion and Management, 51(1), pp. 81 - 88, (2010).

[10] Wu, Z., Du, R., "Design and experimental study of a miniature vapor compression refrigeration system for electronics cooling," Applied Thermal Engineering, 31(2-3), pp. 385 - 390, (2011).

[11] Yuan, W., Yang, B., Yang, Y., Ren, K., Xu, J., and Liao, Y., "Development and experimental study of the characteristics of a prototype miniature vapor compression refrigerator, Applied Energy, Vol. 143, pp. 47 - 57, (2015).

[12] Oliveira, P. A. D., and Barbosa, J. R., "Novel two-phase jet impingement heat sink for active cooling of electronics devices," Applied Thermal Engineering 112, pp. 952 - 964, (2017).

[13] Chamund, D. J., Coulbeck, L., Newcombe, D. R., Waind, P. R., "High power density IGBT module for high reliability applications," IEEE $6^{\text {th }}$ Int. Power Electronics and Motion Control Conference, 17-20 May 2009, Wuhan, China.

[14] Saums, D.L., "Vaporizable dielectric fluid cooling of IGBT power semiconductors, Proc. Int. Symposium on Microelectronics, IMAPS 2009, pp. 238 - 249, (2009).

[15] Soupremanien, U., Person, S. L., Favre-Marient, M., Bultel, Y., “Tools for designing the cooling system of a proton exchange membrane fuel cell," Applied Thermal Engineering 40, pp. 161 - 173, (2012). 
[16] Barreras, F., Lozano, A., Barroso, J., Roda, V., Maza, M., "Theoretical model for the optimal design of air cooling systems of polymer electrolyte fuel cells: application to a high-temperature PEMFC", Fuel Cells, 13 (2), pp. 227 - 237, (2013).

[17] Pandiyan, S., Jayakumar, K., Rajalakshmi, N., Dhathathreyan, K.S., "Thermal and electrical energy management in A PEMFC stack - an analytical approach,” Int. J. Heat Mass Transfer, 51(3-4), pp. 469 - 473, (2008).

[18] Gao, F., Blunier, B., and Miraoui, A., Proton Exchange Membrane Fuel Cell Modelling, ISTE Ltd. and John Willey and Sons, Inc., (2012).

[19] Pei, H., Liu, Z., Zhang, H.,Yu, Y., Tu, Z., Wan, Z., Liu, W., "In situ measurement of temperature distribution in proton exchange membrane fuel cell I: a hydrogen-air stack", J. Power Sources, 227, pp. 72 - 79, (2013).

[20] Taliba, S. F. A., W.H. Azmib, I. Zakariaa, W. Mohameda, A.M.I. Mamata, H. Ismaila, W.R.W. Daudc, "Thermophysical properties of silicon dioxide $\left(\mathrm{SiO}_{2}\right)$ in ethylene glycol/water mixture for proton exchange membrane fuel cell cooling application", Energy Procedia 79 ( 2015 ) $366-371$

[21] Zakaria, I. W.A.N.W. Mohamed, W.H. Azmi, A.M.I. Mamat, R. Mamat, "Thermo-electrical performance of PEM fuel cell using Al2O3 nanofluids," Int. J. Heat and Mass Transfer 119, 460-471, (2018)

[22] Silva, A. P., Renan M. Galante, Pablo R. Pelizza, Edson Bazzo, “A combined capillary cooling system for fuel cells”, Applied Thermal Engineering 41, 104-110, (2012)

[23] Oro, M. V., Bazzo, E., "Flat heat pipes for potential application in fuel cell cooling", Applied Thermal Engineering 90 (2015) $848 \mathrm{e} 857$

[24] Berkeley, L. and Mahdavi, R., "Liquid cooling vs. air cooling evaluation in the Maui high performance computing centre", Federal Energy Management Program (FEMP, (2014).

[25] Marcinichen, J.B., Olivier, J.A., Lamaison, N., Thome, J.R., “Advances in Electronics Cooling”, Heat Transfer Engineering, 34 (5-6), pp. $434-446,(2013)$.

[26] Al-Zaidi, A. H., M. M. Mahmoud, T. G. Karayiannis, "Flow boiling in microchannels with HFE-7100: Experimental results and comparison with correlations", $16^{\text {th }}$ Int. Heat Transfer Conf. IHTC16, China National Convention Center, Bejin, China, $10-15$ August, (2018).

[27] M. M. Mahmoud and T. G. Karayiannis, "Performance of a micro scale integrated thermal management system", $5^{\text {th }}$ Micro and Nano Flows Conf., Milan, Italy 11 - 14, September, (2016)

[28] Al-Zaidi, A. H., M. M. Mahmoud, T. G. Karayiannis, "Condensation flow patterns and heat transfer in horizontal microchannels," Experimental Thermal and Fluid Science, 90, 153 - 173, (2018)

[29] Shah, R.K., and Sekulić, D.P., Fundamentals of Heat Exchanger Design. John Willey and Sons, Inc., (2003).

[30] Mehendale, S.S., Jacobi, A.M., Shah, R.K., "Fluid flow and heat transfer at micro- and meso-scales with application to heat exchanger design," Applied Mechanics Reviews, 53, (7), pp. 175 - 193, (2000).

[31] Kandlikar, S. G., and Grande, W. J., "Evolution of microchannel flow Ppssages - thermohydraulic performance and fabrication technology," Heat Transfer Engineering, 25, (1), pp. 3 - 17, (2003).

[32] Brauner, N., Moalem-Maron, D., "Identification of the range of small diameter conduits, regarding two-phase flow pattern transitions," Int. Communications in Heat Mass Transfer, 19, pp. 29 - 39, (1992).

[33] Ulmann, A. and Brauner, N., "The prediction of flow pattern maps in minichannels", Multiphase Science and Technology, Vol. 19, no. 1, pp. $49-73,(2007)$.

[34] Cornwell, P. A. K., and Kew, P. A., "Boiling in small parallel channels", In Energy Efficiency in Process Technology, ed. P. A. Pilavachi, Elsevier Applied Science, London, pp. 624 - 638, (1993).

[35] Suo, M., and Griffith, P., "Two-phase flow in capillary tubes," J. Basic Engineering, 86, pp. 576-582, (1964).

[36] Triplett, K.A., Ghiaasiaan, S.M., Abdel-Khalik, S.I., Sadowski. D.L., "Gas-liquid two-phase flow in microchannels, part I: twophase flow patterns," Int. J. Multiphase Flow, 25, pp. 377 - 394, (1999).

[37] Harirchian, T. and Garimella, S. V., "A comprehensive flow regime map for microchannel flow boiling with quantitative transition criteria," Int. J. Heat Mass Transfer, Vol. 53, pp.2694-2702, (2010).

[38] Tibirica, C.B., Ribatski, G., "Flow Boiling Phenomenological Differences Between Micro-And Macroscale Channels", Heat Transfer Engineering, 36 (11), pp. 937 - 942, (2015).

[39] Chen, L., Tian, Y.S., and Karayiannis, T.G., "The effect of tube diameter on vertical two-phase flow regimes in small tubes," Int. J. Heat Mass Transfer, 49, pp. 4220-4230, (2006).

[40] Ong, C.L., and Thome, J.R., "Macro-to-microchannel transition in two-phase flow: part 1- two phase flow patterns and film thickness measurements", Exp. Thermal and Fluid Science, Vol. 35, pp. 37-47, (2011).

[41] Yen, T. H., Kasagi, N., Suzuki, Y. "Forced convective boiling heat transfer in microtubes at low mass and heat fluxes", Int. J. of Multiphase Flow,29 (12), pp. 1771-1792. (2003)

[42] Peng, X.F., Hu, H. Y.,Wang, B. X. "Boiling nucleation during liquid flow in microchannels", Int. J. Heat Mass Transfer, 41, pp.101-106, (1998).

[43] Ghiaasiaan, S. M., Chedester, R.C. "Boiling incipience in microchannels," Int. J. of Heat and Mass Transfer, 45, pp.4599-4606, (2002).

[44] Lee, M., Cheung,L. S. L., Lee, Y-K, "Height effect on nucleation site activity and size-dependent bubble dynamics in microchannel convective boiling," J. of Micromechanics and Microengineering, 15, pp. 2121 - 2129, (2005).

[45] Li, J., Peterson,G. P., "Boiling nucleation and two phase flow patterns in forced liquid flow in microchannels," Int. J. of Heat and Mass Transfer, 48, pp. 4797 - 4810, (2005).

[46] Hsu, Y.Y. "On the size range of active nucleation cavities on a heating surface," J. Heat Transfer, 84, pp. 207-215, (1962).

[47] Wang, G., Cheng, P., "Subcooled flow boiling and microbubble emission boiling phenomena in a partially heated microchannel," Int. J. Heat and Mass Transfer, 52, pp. 79 - 91, (2009).

[48] Rayleigh, L. "On the pressure developed in a liquid during the collapse of a spherical cavity", Phil. Mag., 34, pp. 94- 98, (1917).

[49] Forester, H. K. and Zuber, N. "Growth of vapor bubbles in superheated liquid”, J. Appl. Phys., 25, pp. 474- 478, (1954). 
[50] Lee, M., Wong, Y.Y., Wong, M., Zohar, Y., "Size and shape effects on two-phase flow patterns in microchannel forced convection boiling", J. of Micromechanics and Microengineering, 13 (1), pp. 155-164, (2003).

[51] Lee, P. C., Tseng, F.G., Pan, C. "Bubble dynamics in microchannels, Part I: single microchannel," Int. J. of Heat Mass Transfer, 47, pp. 5575-5589, (2004).

[52] Lee, J. Y., Kim, M-H., Kaviany, M., Son,S. Y. "Bubble nucleation in microchannel flow boiling using single artificial cavity," Int. J. Heat Mass Transfer, 54, pp. 5139-5148, (2011).

[53] Yin, L., Jia, L., Mingchen, X. "Experimental investigation on bubble sliding during subcooled flow boiling in microchannel," Exp. Thermal and Fluid Science,68, pp. 435-441, (2015).

[54] Klausner, J. F., Mei, R., Bernhard, D. M,Zeng,L. Z. "Vapor bubble departure in forced convection boiling", Int. J. Heat Mass Transfer, 36. no. 3, pp. 651-662, (1993).

[55] Hong, K. T., Imadojemu, H., Webb,R. L. "Effect of oxidation and surface roughness on contact angle," Exp. Thermal and Fluid Science, 8, pp. 279- 285, (1994).

[56] Kandlikar, S. G., Steinke,M. E., "Contact angles and interface behaviour during rapid evaporation of liquid on a heated surface," Int. J. of Heat Mass Transfer, 45, pp. 3771-3780, (2002).

[57] Kandlikar, S. G.,Spiesman,P. H., "Effect of surface characteristics on flow boiling heat transfer," In Engineering Foundation Conference on Convective and Pool Boiling, pp. 191-197, (1997).

[58] Jones, B. J., Garimella,S. V. "Surface roughness effects on flow boiling in microchannels," J. of Thermal Science and Engineering Applications, December, 1 / 041007-1- 041007-9, (2009).

[59] Alam, T., Lee,P. S., Yap,C. R. "Effects of surface roughness on flow boiling in silicon microgap heat Sinks," Int. J. of Heat and Mass Transfer, 64, pp. 28-41, (2013).

[60] Mahmoud, M.M., Karayiannis, T.G., Kenning, D.B.R. "Surface effects in flow boiling of R134a in microtubes," Int. J. of Heat and Mass transfer, 54, pp. 3334 - 3346, (2011).

[61] Cooper, M. G. "Saturated nucleate pool boiling - a simple correlation," In first UK National Heat Transfer Conference, IChemE Symposium, 86, 2, pp.785-793, (1984).

[62] Ishii, M. "Drift flux model and derivation of kinematic constitutive laws", Two-phase flows and Heat Transfer, 1, pp. 187 - 208, (1977).

[63] Cioncolini, A., Thome, J. R. "Void fraction prediction in annular two-phase flow". Int. J. of Multiphase Flow, 43, pp. 72-84, (2012).

[64] Thome, J., Cioncolini, A. "Unified modeling suite for two-phase flow, convective boiling, and condensation in macro and microchannels," Heat Transfer Engineering, 37(13-14), pp. 1148 - 1157, (2016).

[65] Ammerman, C. N., You,S. M. "Enhancing small-channel convective boiling performance using a microporous surface coating," J. Heat Transfer, 123(5), pp. 976 - 983, (2001).

[66] Yang, F.,Li, W., Dai, Z., Chen, L. "Flow boiling heat transfer of HFE-7000 in nanowire-coated microchannels," Applied Thermal Engineering, 93, pp. 260-268, (2016).

[67] Khanikar, V., Mudawar, I., Fisher, T.," Effects of carbon nanotube coating on flow oiling in a micro-channel," Int. J. of Heat and Mass Transfer, 52, 3805-3817, (2009).

[68] Morshed, A.K.M. M., Paul, T. C., Khan, J. "Effect of $\mathrm{Cu}-\mathrm{Al}_{2} \mathrm{O}_{3}$ nanocomposite coating on flow boiling performance of a microchannel", Applied Thermal Engineering, 51, pp. 1135-1143, (2013).

[69] Kim, J. M., Soon, H. K., In Yu, D., Hyun, S. P., Moriyama, K., Kim,M. H., "Smart surface in flow boiling: spontaneous change of wettability", Int. J. of Heat and mass Transfer, 105, pp. 147-156, (2017).

[70] Bai, P., Tang, T., Tang, B., "Enhanced flow boiling in parallel microchannels with metallic porous coating," Applied Thermal Engineering, 58, pp. 291-297, (2013).

[71] Kaya, A., Demiryürek, R., Armagan, E., Ozaydin-Ince, G., Sezen, M., Kosar, A., "Boiling heat transfer enhancement in mini/microtubes via polyhydroxyethylmethacrylate (pHEMA) coatings on inner microtube walls at high mass fluxes", J. of Micromechanics and Microengineering, 23, no. 11, 115017, (2013).

[72] Nedaei, M., Armagan, E., Sezen, M., Ince,G. O., Kosar, A., "Enhancement of flow boiling heat transfer in pHEMA/pPFDA coated microtubes with longitudinal variations in wettability", AIP Advances, 6, 035212, (2016).

[73] Al-Gaheeshi, A. M., Mahmoud, M.M., Karayiannis, T.G., "Flow boiling heat transfer in a vertical small-diameter tube: effect of different fluids and surface characteristics", Proc. of the 4th Int. Forum on Heat Transfer, IFHT2016 November 2-4, 2016, Sendai, Japan.

[74] Jabardo, J. M. S., Ribatski, G., Stelute, E., "Roughness and surface material effects on nucleate boiling heat transfer from cylindrical surfaces to refrigerants R-134a and R-123", Exp. Thermal and Fluid Science,33, pp. 579-590, (2009).

[75] Hosseini, R., Gholaminejad, A.,Nabil, M., "Concerning the effect of surface material on nucleate boiling heat transfer of R-113", J. of Electronics Cooling and Thermal Control, 1, pp. 22-27, (2011).

[76] Zou, L., Jones, B. G. (2013). "Heating surface material's effect on subcooled flow boiling heat transfer of R134a”, Int. J. of Heat and Mass Transfer, 58, pp. 168-174.

[77] Cooper, M. G., "The microlayer and bubble growth in nucleate pool boiling”, Int. J. Heat and Mass Transfer, 12, pp. 915 - 933 , (1969).

[78] Pike-Wilson, E.A., Karayiannis, T.G. "Flow boiling of R245fa in $1.1 \mathrm{~mm}$ diameter stainless steel, brass and copper tubes," Exp. Thermal and Fluid Science, 59, pp. 166-183, (2014).

[79] Saitoh, S., Daiguji, H., Hihara, E. "Effect of tube diameter on boiling heat transfer of R-134a in horizontal small-diameter tubes," Int. J. of Heat and Mass Transfer, 48(23-24), pp. 4973-4984, (2005).

[80] Consolini, L. and Thome, J. R. "Micro-channel flow boiling heat transfer of R-134a, R-236fa, and R-245fa," Microfluidics and Nanofluidics, 6 (6), pp. 731-746, (2009). 
[81] Mahmoud, M. M., Kenning, D.B.R.,Karayiannis, T.G. "Single and two phase heat transfer and pressure drop in a $0.52 \mathrm{~mm}$ vertical metallic tube. $7^{\text {th }}$ Int. Conf. on Enhanced, Compact and Ultra-compact Heat Exchangers: From Microscale Phenomena to Industrial Applications, September 13 - 18, (2009), Heredia, Costa Rica.

[82] Karayiannis, T. G., Mahmoud, M.M., Kenning, D.B.R. (2012). "A study of discrepancies in flow boiling results in small to microdiameter metallic tubes,” Exp. Thermal and Fluid Science, 36, pp. 126-142.

[83] Chen, L., Tian, Y.S., Karayiannis, T.G. "The effect of tube diameter on vertical two-phase flow regimes in small tubes," Int. J. of Heat and Mass Transfer, 49 (21-22), pp. 4220-4230, (2006).

[84] Huo, X., Chen, L., Tian, Y.S., Karayiannis, T.G. "Flow boiling and flow regimes in small diameter tubes", Applied Thermal Engineering, 24, pp. 1225 - 1239, (2004).

[85 Ong, C. L. and Thome, J.R. "Macro-to-microchannel transition in two-phase flow: Part 2-Flow boiling heat transfer and critical heat flux," Exp. Thermal and Fluid Science, 35(6), pp. 873-886, (2011).

[86] Charnay, R.,Revellin, R. and Bonjour, J. "Flow boiling characteristics of R-245fa in a minichannel at medium saturation temperatures", Exp. Thermal and Fluid Science, 59, pp. 184-194, (2014).

[87] Charnay, R., Revellin, R. and Bonjour, J. "Flow boiling heat transfer in minichannels at high saturation temperatures: Part 1experimental investigation and analysis of the heat transfer mechanisms," Int. J. Heat Mass Transfer, 87, pp. 636-652, (2015).

[88] Wang, G., Cheng, P., Wu, H., "Unstable and stable flow boiling in parallel microchannels and in a single microchannel," Int. J. Heat Mass Transfer, 50 (21-22), pp. 4297-4310, (2007).

[89] Fu, X., Qi, S.L., Zhang, P., Wang, R.Z., "Visualization of flow boiling of liquid nitrogen in a vertical mini-tube, “ Int. J. Multiphase Flow, 34 (4), pp. 333-351, (2008).

[90] Aligoodarz, M. R., Yan, Y. and Kenning, D. B. R., "Wall temperature and pressure variations during flow boiling in narrow channels", Proc.1 $1^{\text {th }}$ Int. Heat Transfer Conference (IHTC), August 23-28, 2, pp.225-230, (1998).

[91] Qi, S.L., Zhang, P. Wang, R.Z. and Xu, L.X., "Flow boiling of liquid nitrogen in micro-tubes: part I - the onset of nucleate boiling, two-phase flow instability and two-phase flow pressure drop,” Int. J. Heat Mass Transfer, 50 (25-26), pp. 4999-5016, (2007).

[92] Bogojevic, D., Sefiane, K., Walton, A. J., Lin, H. and Cummins, G., "Two-phase flow instabilities in a silicon microchannels heat sink," Int. J. Heat Fluid Flow, 30, pp. 854-867, (2009).

[93] Wang, W., Sefiane, K., Wang, Z-g, and Harmand, S., "Analysis of two phase pressure drop fluctuations during microchannel flow boiling," Int. J. Heat Mass Transfer, 70, pp. 353 - 362, (2014).

[94] Özdemir, M. R., Mahmoud, M. M. and Karayiannis, T. G., "Flow boiling heat transfer in a rectangular copper microchannel," Int. conf. on advances in mechanical engineering, 13-15 may 2015, Yildiz Technical University, Istanbul, Turkey, (2015)

[95] Yan, Y. and Kenning, D.B.R., "Pressure and temperature fluctuations during boiling in narrow channel". In Eurotherm, Heat Transfer in Condensation and Evaporation, Grenoble, 62, pp.107-1223, (1998).

[96] Gedupudi, S., Zu, Y. Q., Karayiannis, T. G., Kenning, D. B. R., and Yan, Y. Y., "Confined bubble growth during flow boiling in a mini/micro-channel of rectangular cross-section part I: experiments and 1-D modelling," Int. J. Thermal Sciences, 50, pp. $250-266,(2011)$.

[97] Kandlikar, S. G., "Nucleation characteristics and stability considerations during flow boiling in microchannels," Exp. Thermal Fluid Sciences, 30, pp. 441-447, (2006).

[98] Fayyadh, E., M., M. M. Mahmoud, and T. G., Karayiannis, "Flow boiling heat transfer of R134a in multi microchannels," Int. J.Heat and Mass Transfer, 110, pp. 422 - 436, (2017).

[99] Al-Zaidi A., "Flow boiling and condensation with refrigerant HFE-7100 for cooling high heat flux systems," PhD Thesis, in preparation, Brunel University London.

[100] Koşar, A., Kuo, C.-J., Peles, Y., « Suppression of boiling flow oscillations in parallel microchannels by inlet restrictors.” J. Heat Transfer, 128 (3), pp. 251-260, (2006).

[101] Kuan, W.K., Kandlikar, S.G., "Experimental study on the effect of stabilization on flow boiling heat transfer in microchannels." Heat Transfer Engineering, 28 (8-9), pp. 746-752, (2007).

[102] Lu, C.T., and Pan, C., "Stabilization of flow boiling in microchannel heat sinks with a diverging cross-section design," $J$. Micromechanics and Microengineering, 18 (7), 075035, (2008).

[103] Singh, S.G., Kulkarni, A., Duttgupta, S. P., Puranik, B.P., Agrawal, A., "Impact of aspect ratio on flow boiling on water in rectangular microchannels". Exp. Thermal and Fluid Science, 33, pp. 153-160, (2008).

[104] Soupremanien, U., Le Person, S., Favre-Marnet, M., Bultel, Y., "Influence of the aspect ratio on boiling flows in rectangular mini-channels," Exp. Thermal and Fluid Science, 35, pp. 797-809, (2011).

[105] Markal, B., Aydin, O., Avci, M., "Effect of aspect ratio on saturated flow boiling in microchannels," Int. J. of Heat and Mass Transfer, 93, pp. 130-143, (2016).

[106] Fu, B.R., Lee, C.Y., Pan, C., "The effect of aspect ratio on flow boiling heat transfer of HFE-7100 in a microchannel heat sink", Int. J. of Heat and Mass Transfer, 58, pp. 53-61, (2013).

[107] Özdemir, R. M., Mahmoud, M. M., Karayiannis, T. G., "Flow boiling of water in a rectangular metallic microchannel," Under Review, Int. J. of Thermal Sciences, (2018).

[108] Al-Zaidi, A. H., Mahmoud, M. M., Karayiannis, T. G., "Flow boiling of HFE-7100 in multi-microchannels: aspect ratio effect," $6^{\text {th }}$ Micro and Nano flows Conf., Atlanta, USA, 9-12 Sept. (2018).

[109] Bao, Z. Y., Fletcher, D. F., Haynes, B. S., "Flow boiling heat transfer of Freon R11 and HCFC123 in narrow passages", Int. J. Heat Mass Transfer, 43, pp. 3347-3358, 2000.

[110] Anwar, Z., Palm, B., Khodabandeh, R., "Flow boiling heat transfer and dryout characteristics of R152a in a vertical mini-channel, Exp. Thermal Fluid Science, 53, pp. 207-217, (2014).

[111] Mahmoud, M.M., Kenning, D.B.R., and Karayiannis, T.G., "Single and two phase heat transfer and pressure drop in a $0.52 \mathrm{~mm}$ vertical metallic tube. $7^{\text {th }}$ Int. Conf. on Enhanced, Compact and Ultra-Compact Heat Exchangers: From Microscale Phenomena to Industrial Applications, Heredia, Costa Rica, 13-18 September, (2009). 
[112] Lin, s., Kew, p. a., and Cornwell, k., "Flow boiling of refrigerant R141b in small tubes", Transactions of the Institution of Chemical Engineers, 79 (A), PP. 417-424, (2001).

[113] McNeil, D. A., Raeisi, A. H., Kew, P. A., Hamed, R. S., "Flow boiling heat-transfer in micro to macro transition flows," Int. J. Heat Mass Transfer, 65, PP. 289-307, (2013).

[114] Qu, W. and I. Mudawar. "Flow boiling heat transfer in two phase microchannel heat sinks: I. experimental investigation and assessment of correlation methods". In. J. Heat Mass Transfer, 46:2755-2771, (2003).

[115] Boye, H., Staate, Y., Schmidt, J., "Experimental investigation and modelling of heat transfer during convective boiling in a minichannel", Int. J. Heat Mass Transfer, 50, pp. 208-215, (2007).

[116] Mortada, S., Zoughaib, A., Arzano-Daurelle, C., Clodic, D., "Boiling heat transfer and pressure drop of R134a and R-1234yf in minichannels for low mass fluxes," Int. J. Refrigeration, 35, pp. 962-973, 2012.

[117] Huh, C., and Kim, M. H., "An experimental investigation of flow boiling in an asymmetrically heated rectangular microchannel," Exp. Thermal Fluid Science, 30, pp. 775-784, (20060.

[118] In, S., Jeong, S., "Flow boiling heat transfer characteristics of R123 and R134a in a micro-channel," Int. J. Multiphase Flow, 35, pp. 987-1000, (2009).

[119] Ali, R., Palm, B., Maqbool, M. H., "Flow boiling heat transfer of refrigerants R134a and R245fa in a horizontal micro-channel," Exp. Heat Transfer, 25, pp. 181-196, (2012).

[120] Balasubramanian, K., Jagirdar, M., Lee, P. S., Teo, C. J., Chou, S. K., "Experimental investigation of flow boiling heat transfer and instabilities in straight microchannels," Int. Journal Heat Mass Transfer, 66, pp. 655-671, (20130.

[121] Yen, T. H., Kasagi, N., Suzuki, Y., "Forced convective boiling heat transfer in microtubes at low mass and heat Fluxes", Int. J. Multiphase Flow, 29, pp. 1771-1792, 2003.

[122] Basu, S., Ndao, S., Michna, G. J., Peles, Y., Jensen, M.K., "Flow boiling of R134a in circular microtubes-part I: study of heat transfer characteristics", J. Heat Transfer, 133, pp. 051502-1-051502-9, (2011).

[123] Harirchian, T., Garimella, S. V., "Microchannel size effects on local flow boiling heat transfer to a dielectric fluid", Int. J. Heat Mass Transfer, 51, pp. 3724-3735, (2008).

[124] Harirchian, T., Garimella, S. V., "Effects of channel dimension, heat flux, and mass flux on flow boiling regimes in microchannels," Int. J. Multiphase Flow, 35, pp. 349-362, (2009).

[125] Borhani, N., and Thome, J.R., "Intermittent dewetting and dryout of annular flows", Int. J. Multiphase Flow, 67 (s), pp. 144 $152,(2014)$.

[126] Bigham, S., Moghaddam, S., "Microscale study of mechanisms of heat transfer during flow boiling in a microchannel", Int. J. Heat Mass Transfer, 88, pp. 111 - 121, (2015).

[127] Karayiannis, T. G., Pike-Wilson, E. A., Chen, L., Mahmoud, M.M., Tian, Y., "Flow patterns and comparison with correlations for vertical flow boiling of R245fa in small to micro tubes", $4^{\text {th }}$ Micro and Nano Flows Conf., UCL, London, UK, 7-10 September, (2014).

[128] Mahmoud, M.M., Karayiannis, T.G., "Flow pattern transition models and correlations for flow boiling in mini-tubes," J. Exp. Thermal Fluid Sciences, 70, pp. 270 - 282, (2016).

[129] Mahmoud, M.M., Karayiannis, T.G., "Heat transfer correlation for flow boiling in small to micro tubes", Int. J. Heat Mass Transfer, 66, pp. 553 - 574, (2013).

[130] Mahmoud, M., and Karayiannis, T., "A Statistical correlation for flow boiling heat transfer in micro tubes". Proceedings of the $3^{\text {nd }}$ European Conf on Microfluidics - Microfluidics 2012, Heidelberg, Germany, December 3 - 5, (2012).

[131] Mahmoud, M. M., Karayiannis, T.G., and Kenning, D.B.R., in Emerging Topics in Heat Transfer Enhancement and Heat Exchangers, Chapter 10, pp. 321-396, WIT Press, 2014.

[132] Anwar, Z., Palm, B., Khodabandeh, R., "Flow boiling of R600a in a uniformly heated vertical minichannel," Proc. $13^{\text {th }}$ UK Heat Transfer Conf, Imperial College London, (2013).

[133] Anwar, Z., Palm, B., Khodabandeh, R. "Flow boiling heat transfer and dryout characteristics of R152a in a vertical mini-channel," Exp. Thermal and Fluid Science, 53, pp. 207-21, (2014)

[134] Chen, J.C., "A correlation for boiling heat transfer to saturated fluids in convective flow," Industrial and Engineering Chemistry, $5: 322-329,(1966)$. 